\title{
Theoretical Determination of Influence of the Metallic State of Oxidation toward Cytotoxic Activity: Case of Ruthenium Complexes
}

\author{
Bamba Kafoumba*, Ouattara Wawohinlin Patrice, Diarrassouba Fatogoma, \\ Lamoussa Ouattara, Massapihanhoro Pierre Ouattara, Kouakou Nobel N'guessan, \\ Ehouman Ahissan Donatien, Ziao Nahossé
}

Laboratoire de Thermodynamique et Physico-Chimie du Milieu, Université Nangui Abrogoua, Abidjan, Côte d'Ivoire

Email: ^bambakaf.sfa@univ-na.ci

How to cite this paper: Kafoumba, B., Patrice, O.W., Fatogoma, D., Ouattara, L., Ouattara, M.P., N'guessan, K.N., Donatien, E.A. and Nahossé, Z. (2021) Theoretical Determination of Influence of the Metallic State of Oxidation toward Cytotoxic Activity: Case of Ruthenium Complexes. Computational Chemistry, 9, 97-119.

https://doi.org/10.4236/cc.2021.92006

Received: March 6, 2021

Accepted: April 27, 2021

Published: April 30, 2021

Copyright $\odot 2021$ by author(s) and Scientific Research Publishing Inc. This work is licensed under the Creative Commons Attribution International License (CC BY 4.0).

http://creativecommons.org/licenses/by/4.0/

\begin{abstract}
Ruthenium complexes present two states of oxidation that are $\mathrm{Ru}(\mathrm{II})$ and $\mathrm{Ru}(\mathrm{III})$. Both are assumed to present cytotoxic activity at ground state. On the purpose of highlighting their differences, DFT, TD-DFT and NBO have been performed at both Wb97xd/Lanl2dz and B3lyp/Lanl2dz levels. NBO program shows that both groups of ruthenium complexes present almost the same charge of Ru atom. Moreover, they display nearly the same structure of valence orbitals of the ruthenium. However, when it comes to compare their frontier orbitals HOMO and LUMO, we notice that the chloride atom has a great influence on their energy. The lack of Chloride atoms reduces the energy of frontier orbitals regardless of the functional. And the more the number of chloride atoms, the higher the energy. Also, $\mathrm{RuCl}_{3}$ Terpy and $\alpha$ - $\mathrm{RuCl}_{2}$ (Azpy) $)_{2}$ have been discovered to display the best energy suitable for reaction as cytotoxic agents. Yet, both are from groups different. Thus, at ground state, there is practically no difference between both groups. However, regarding TDDFT prediction with the determination of vertical electronic affinity VEA and vertical ionization potential VIP both at ground state $S$ and at exciting $\mathrm{T} 1$ state, we notice that $\mathrm{Ru}(\mathrm{II})$ complexes are not active either in the presence or absence of ${ }^{3} \mathrm{O}_{2}$ molecule. Here, only $\mathrm{Ru}$ (III) complexes are able to react on Guanine through their radical cations or by generating the superoxide radical anion $\mathrm{O}_{2}^{--}$. Therefore, the $\mathrm{Ru}(\mathrm{III})$ complexes are assumed to be active both at a fundamental state and under the effect of light for photodynamic therapy. We come to conclude that $\mathrm{Ru}(\mathrm{II})$ complexes are not active by excitation as their valence electrons are paired thereby making these complexes more stable. Besides, Fac-Ru(Azpy ${ }_{3}^{2+}$, a Ru(II) molecule that is
\end{abstract}


not active at ground state owing certainly to its $\mathrm{C}_{3}$ symmetry or Azpy ligand presents all the same a difficult activity on generating $\mathrm{O}_{2}^{--}$. For the coming paper, we intend to check whether $\mathrm{Ru}(\mathrm{II})$ complex can be active under the effect of light if it is in a triplet charge state.

\section{Keywords}

NBO, TD-DFT, Ru(II), Ru(III), Photo-Dynamic Therapy (PDT)

\section{Introduction}

Cancer is known as a widespread and mortal disease. Thus, investigations are currently made to eradicate it. Besides, since discovered, many forms of cancer are known today [1] [2]. They require different types of treatment such as chemotherapy, radiotherapy, surgery, and even their combination through photodynamic therapy (PDT) [3]. Although the tremendous success of researchers improves the technic to eradicate the disease, the patient is still exposed to the side effects. Namely, the patient can be confronted with the loss of healthy cells. He can also undergo nausea thereby losing appetite or losing absolutely an organ. He can also undergo vomiting, hair loss, and damage to the kidney [4].

In chemotherapy, many types of drugs are used. The first one has hitherto been the cisplatin molecule and its derivatives [5] [6] [7] [8] [9]. Since these molecules were assumed to present more side effects although their efficiency, other molecules are explored. We can number natural molecules like coumarins [10] [11] and metallic complexes [12]. Regarding these metallic complexes, ruthenium complexes are of great interest. Their particularity is that they have many oxidation states and can easily make difference between ill and healthy cells thereby reducing drastically the toxic effects [13]. They are also of great interest because of their capacity to mimic the transferrin when they are bonded to the biological molecules in the blood [14]. The first complexes discovered are ruthenium complexes of bipyridine, azopyridine, and others like NAMI.

The most common fundamental oxidation states of ruthenium known within the complex molecules are states II and III. Both are assumed to react on the DNA by binding covalently to the N7 position of guanin to form 1,2- or 1,3-intrastrand crosslinks, and interstrand crosslinks. Sometimes, molecules that display halogen atoms in their structures are assumed to undergo hydrolysis and the loss of those atoms that favor the linking to the DNA of the infected cells [15]. Yet, certain complexes do not present any halogen atom and they are known for their efficiency and stability as drugs against Cancer diseases [16] [17] [18] [19]. Therefore, how can we explain this discrepancy between those ruthenium complexes; however, they all are discovered active molecules at fundamental state?

Through this work, we intend to find out the key element that renders the 
ruthenium complexes so active cytotoxically regardless their states of oxidation and classify them according to their reactivity. We have focused our research on a series of ruthenium complexes that display states $\mathrm{Ru}(\mathrm{II})$ and $\mathrm{Ru}$ (III) as fundamental oxidation states. We have complexes $\alpha-\mathrm{RuCl}_{2}(\mathrm{Azpy})_{2}$ [20] and $\mathrm{RuCl}_{3}\left(\mathrm{H}_{2} \mathrm{O}\right)_{2} \mathrm{Gly}$ [21], $\mathrm{RuCl}_{3}$ Terpyridine [22], $\left[\mathrm{RuCl}_{4}(\mathrm{Him})_{2}\right]^{-}$(NAMI), $\left[\mathrm{RuCl}_{4}(\mathrm{Him})(\mathrm{DMSO})\right]^{-}$(NAMI-A) [23], Fac-Ru(Azpy $)_{3}^{2+}, \quad \mathrm{Mer}-\mathrm{Ru}(\text { Azpy })_{3}^{2+}$ and $\mathrm{Ru}(\mathrm{Bipy})_{3}^{2+}$ [24] [25]. Respectively, Gly stands for glycoside, Him for imidazoline, Azpy for 2-phenylazopyridine and Bipy for bipyridine. Their first difference that can be noticed is through their ligands that are different from one complex to another. Besides, before pursuing the investigation of the discrepancy that regards their state, we will summarize the description of each complex.

\section{1. $\mathrm{RuCl}_{3}\left(\mathrm{H}_{2} \mathrm{O}\right)_{2} \mathrm{Gly}$}

This molecule was studied by De Sousa et al. [21]. it is considered as a +III state molecule. This molecule is assumed to possess antileishmanial activity [26]. As it presents three isomers, the fac-cis-diaquo-trischloro-glycinatoruthenium III isomer presented in Figure 1 displays the medical activity.

\section{2. $\alpha-\mathrm{RuCl}_{2}(\mathrm{Azpy})_{2}$}

The structure of this molecule is presented in Figure 2. It has much been studied since the discovery of its biological activity [15] [27] [28] [29] [30]. Although the complex shows five isomers due to the antisymetrical shape of the ligand, the cis- $\mathrm{RuCl}$ isomer was tested to display cytotoxic activities against renal cancer

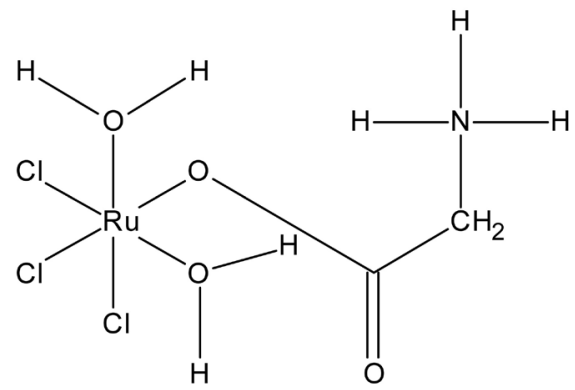

Figure 1. Structure of $\mathrm{RuCl}_{3}\left(\mathrm{H}_{2} \mathrm{O}\right)_{2} \mathrm{Gly}$.

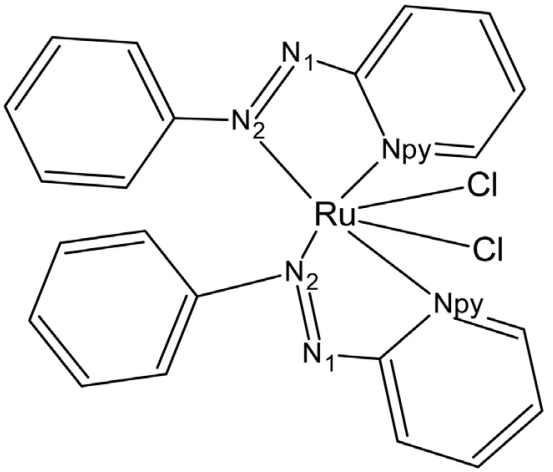

Figure 2. Structure of $\alpha-\mathrm{RuCl}_{2}(\mathrm{Azpy})_{2}$. 
(A498), lung cancer (H226), ovarian cancer (IGROV), breast cancer (MCF-7) and colon cancer (WIDR). The authors assumed that this complex presents the ruthenium atom in its + II state.

\section{3. $\mathrm{RuCl}_{3}$ Terpyridine}

Figure 3 shows the structure of this molecule. It was discovered by Paul M. Van Vliet et al. [22], it presents also two isomers where the mer isomer is admitted as biologically active molecule against leukemia cells. Presenting the $\mathrm{Ru}$ atom in +III state, the molecule is particularly assumed to bind to DNA via the guanine [31].

\subsection{NAMI and NAMI-A}

Both molecules are anti-cancer drugs. Their activities are noticed by the substitution of the chlorine atoms through hydrolysis. They were both discovered after noticing the side effects provoked by cis-platin and its derivatives [32] [33]. Even if they display four chloride atoms in their structure, both complexes are considered with the metal $\mathrm{Ru}$ in its +III state [34] [35]. Figure 4 shows both structures to highlight their difference.

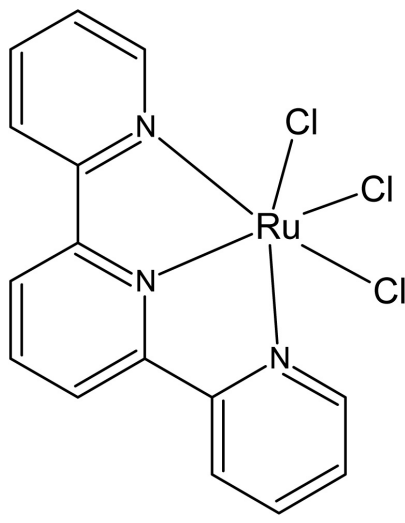

Figure 3. Structure of RuCl3Terpy.

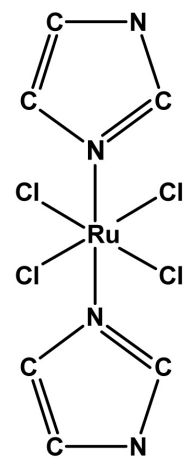

NAMI<smiles></smiles>

NAMI-A

Figure 4. Structure of both NAMI and NAMI-A. 


\subsection{Fac-Ru(Azpy $)_{3}^{2+}$ and $\operatorname{Mer}-\operatorname{Ru}(\operatorname{Azpy})_{3}^{2+}$}

Both complexes are isomers. They show the $\mathrm{Ru}$ atom in the state of $+\mathrm{II}$. Among them, the mer isomer is assumed to be cytotoxic agent against human tumors [36]. What is more, this isomer was especially assumed to be very active against M19 cells more than the cisplatin [24]. However, the Fac isomer that is $C_{3}$ symetrical is reported to appear unlikely [37] inactive owing to the hindrance created by the orientation of the three azpy ligands.

\section{6. $\operatorname{Ru}(\mathrm{Bipy})_{3}^{2+}$}

This complex is assumed to fix the ruthenium atom at $+\mathrm{II}$ state of oxidation. It is a $\mathrm{D}_{3}$ symmetrical and its cytotoxicity was assumed to depend on the metal, the ligand and the shape of the molecule [38]. It is admitted hampering the acetylcholinesterase, which is an enzyme mainly involved in neurotransmittermetabolism [39]. Figure 5 displays the both isomers $\mathrm{Ru}(\text { Azpy })_{3}^{2+}$ and $\mathrm{Ru}(\mathrm{Bipy})_{3}^{2+}$ molecules.

Therefore, we will theoretically deal with the difference between both types of ruthenium complexes. First and foremost, the $\mathrm{Ru}(\mathrm{II})$ are assumed to be more active than R(III) that are biologically inert [40].

\section{Methods}

We performed All calculations by using the Gaussian program package 09 [41]. All the structures were optimized with density functional theory methods at Wb97xd/Lanl2dz and B3lyp/lanl2dz levels. The pseudo potential Lanl2dz was used for $\mathrm{Ru}$ atom which is a heavy atom and displays many inner electrons. These inner electrons are at the origin of relativity that cannot be handled by standard basis set. The calculation of the frequencies shows a lack of imaginaries values thereby confirming the effective stability of the molecules. The Time Dependent Density Functional Theory (TD-DFT) and the Natural Bond Orbital (NBO) calculations were performed at the Wb97xd/Lanl2dz and B3lyp/lanl2dz levels.

The NBO was preformed to find out the charge and the electronic structure of central metal ruthenium and TD-DFT consisted in performing the spectrum of each complex.
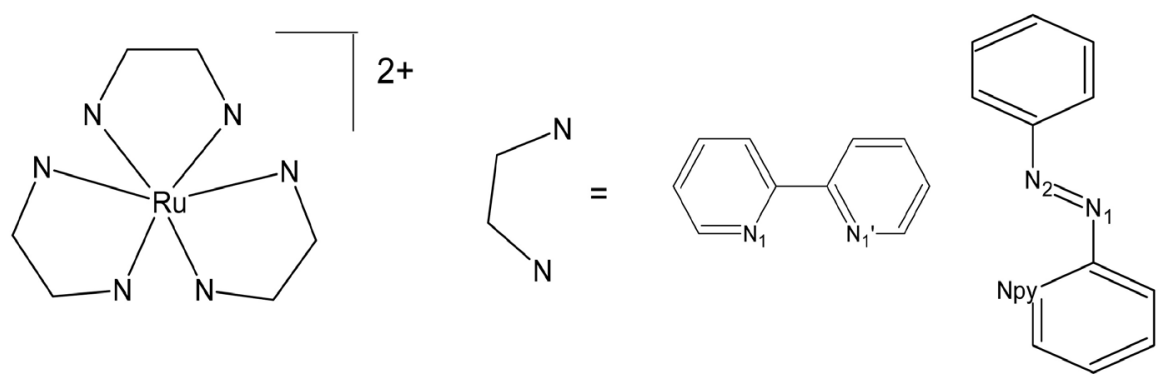

Figure 5. Structure of $\operatorname{Ru}(\mathrm{Bipy})_{3}^{2+}, \operatorname{Mer}-\operatorname{Ru}(\mathrm{Azpy})_{3}^{2+}$ and $\mathrm{Fac}-\mathrm{Ru}(\mathrm{Azpy})_{3}^{2+}$. 


\section{Results and Discussion}

\subsection{Charge of the Ruthenium in the Complex}

All the studied complexes were assumed to be synthesized through $\mathrm{RuCl}_{3} \cdot 3 \mathrm{H}_{2} \mathrm{O}$. yet, they present two types of state according to literature. For the state $+\mathrm{II}$ of the ruthenium named $\mathrm{Ru}(\mathrm{II})$, we have the complexes $\alpha-\mathrm{RuCl}_{2}(\mathrm{Azpy})_{2}$, $\operatorname{Mer}-\mathrm{Ru}(\text { Azpy })_{3}^{2+}, \quad \mathrm{Fac}-\mathrm{Ru}(\text { Azpy })_{3}^{2+}$ and $\mathrm{Ru}(\mathrm{Bipy})_{3}^{2+}$. Regarding the $+\mathrm{III}$ state, we have the complexes NAMI, NAMI-A, $\mathrm{RuCl}_{3}$ Terpy and $\mathrm{RuCl}_{3}\left(\mathrm{H}_{2} \mathrm{O}\right)_{2} \mathrm{Gly}$ including $\mathrm{RuCl}_{3} \cdot 3 \mathrm{H}_{2} \mathrm{O}$. They are $\mathrm{Ru}(\mathrm{III})$ complexes. Table 1 displays the charge calculated through NBO calculation and the electronic valence structure of Ru. We can notice that the values showed by $\mathrm{Ru}$ in each complex cannot make difference between the state of the complexes. Here, we can see that in the first $\mathrm{Ru}$ (II) group calculated with wb97xd method, the charge of $\mathrm{Ru}$ is comprised between 0 to 0.26 . For instance, in both Mer and Fac $\mathrm{Ru}(\text { Azpy })_{3}^{2+}$ the charge is the same indicating that the stereoisomer has no effect on the ruthenium charge. Thus, there is not any difference between both isomers regarding the charge of $\mathrm{Ru}$. Whereas $\alpha-\mathrm{RuCl}_{2}(\mathrm{Azpy})_{2}$, shows a negative charge for $\mathrm{Ru}$ certainly due to both chloride atoms and since both Mer and Fac $\mathrm{Ru}(\mathrm{Azpy})_{3}^{2+}$ derives from it. It means that the substitution of both chloride atoms by a bidentate Azpy ligand increases the ruthenium's charge. Regarding B3lyp method, we can notice that both Mer and Fac $\mathrm{Ru}(\text { Azpy })_{3}^{2+}$ have still the same charge confirming the lack of difference between them. Whereas the $\alpha-\mathrm{RuCl}_{2}(\mathrm{Azpy})_{2}$ at B3lyp/Lanl2dz level, it shows that the presence of $\mathrm{Cl}$ atoms permits to increase the charge of $\mathrm{Ru}$.

Concerning the second $\mathrm{Ru}(\mathrm{III})$ group, we can see in NAMI that Ru has a very small charge of 0.02. However, NAMI-A presents a negative charge of -0.21 and $\mathrm{RuCl}_{3}$ (Terpy) shows 0.13 as charge of $\mathrm{Ru}$. Besides, $\mathrm{RuCl}_{3} \cdot 3 \mathrm{H}_{2} \mathrm{O}$ presents 0.31 as $\mathrm{Ru}$ charge that is smaller than the charge displayed in $\mathrm{RuCl}_{3}\left(\mathrm{H}_{2} \mathrm{O}\right)_{2} \mathrm{Gly}(0.34)$. Yet, the $\mathrm{RuCl}_{3} \cdot 3 \mathrm{H}_{2} \mathrm{O}$ is also known to present a state $+\mathrm{III}$. Therefore, we can assume that the ruthenium charge does not predict the oxidation state of the

Table 1. Charge and natural valence structure of ruthenium calculated at Wb97xd/Lanl2dz and B3lyp/Lanl2dz levels.

\begin{tabular}{|c|c|c|c|c|c|}
\hline \multirow{2}{*}{ Group } & \multirow{2}{*}{ Complex } & \multicolumn{2}{|c|}{ Ru charge } & \multicolumn{2}{|c|}{ Natural electron structure of $\mathrm{Ru}$} \\
\hline & & Wb97xd & B3lyp & Wb97xd & B3lyp \\
\hline \multirow{4}{*}{$\mathrm{Ru}(\mathrm{II})$} & $\alpha-\mathrm{RuCl}_{2}(\mathrm{Azpy})_{2}$ & -0.01 & 0.59 & $4 \mathrm{~d}^{7.07} 5 \mathrm{~s}^{0.27} 5 \mathrm{p}^{0.01} 5 \mathrm{~d}^{0.04} 6 \mathrm{p}^{0.64}$ & $4 \mathrm{~d}^{7.08} 5 \mathrm{~s}^{0.27} 5 \mathrm{p}^{0.01} 5 \mathrm{~d}^{0.04} 6 \mathrm{p}^{0.03}$ \\
\hline & Fac-Ru(Azpy $)_{3}^{2+}$ & 0.17 & 0.20 & $4 \mathrm{~d}^{7.14} 5 \mathrm{~s}^{0.23} 5 \mathrm{p}^{0.44} 5 \mathrm{~d}^{0.03} 6 \mathrm{p}^{0.01}$ & $4 \mathrm{~d}^{7.14} 5 \mathrm{~s}^{0.23} 5 \mathrm{p}^{0.44} 5 \mathrm{~d}^{0.03} 6 \mathrm{p}^{0.01}$ \\
\hline & $\operatorname{Mer}-\operatorname{Ru}(\text { Azpy })_{3}^{2+}$ & 0.17 & 0.20 & $4 \mathrm{~d}^{7.14} 5 \mathrm{~s}^{0.23} 5 \mathrm{p}^{0.44} 5 \mathrm{~d}^{0.03} 6 \mathrm{p}^{0.01}$ & $4 d^{7.12} 5 s^{0.23} 5 p^{0.43} 5 d^{0.03} 6 p^{0.01}$ \\
\hline & $\operatorname{Ru}(\text { Bipy })_{3}^{2+}$ & 0.26 & 0.62 & $4 \mathrm{~d}^{7.16} 5 \mathrm{~s}^{0.18} 5 \mathrm{p}^{0.27} 5 \mathrm{~d}^{0.03} 6 \mathrm{p}^{0.12}$ & $4 \mathrm{~d}^{7.15} 5 \mathrm{~s}^{0.23} 5 \mathrm{p}^{0.42} 5 \mathrm{~d}^{0.03} 6 \mathrm{p}^{0.01}$ \\
\hline \multirow{5}{*}{$\mathrm{Ru}(\mathrm{III})$} & NAMI & 0.02 & 0.70 & $4 \mathrm{~d}^{6.88} 5 \mathrm{~s}^{0.29} 5 \mathrm{p}^{0.76} 5 \mathrm{~d}^{0.04} 6 \mathrm{p}^{0.01}$ & $4 \mathrm{~d}^{6.94} 5 \mathrm{~s}^{0.29} 5 \mathrm{p}^{0.03} 5 \mathrm{~d}^{0.04} 6 \mathrm{p}^{0.01}$ \\
\hline & NAMI-A & -0.21 & 0.54 & $4 \mathrm{~d}^{7.01} 5 \mathrm{~s}^{0.32} 5 \mathrm{p}^{0.83} 5 \mathrm{~d}^{0.05} 6 \mathrm{p}^{0.01}$ & $4 \mathrm{~d}^{7.07} 5 \mathrm{~s}^{0.32} 5 \mathrm{p}^{0.02} 5 \mathrm{~d}^{0.04} 6 \mathrm{p}^{0.01}$ \\
\hline & $\mathrm{RuCl}_{3}$ Terpy & 0.13 & 0.07 & $4 \mathrm{~d}^{6.83} 5 \mathrm{~s}^{0.28} 5 \mathrm{p}^{0.72} 5 \mathrm{~d}^{0.04} 6 \mathrm{p}^{0.01}$ & $4 \mathrm{~d}^{6.91} 5 \mathrm{~s}^{0.28} 5 \mathrm{p}^{0.70} 5 \mathrm{~d}^{0.04} 6 \mathrm{p}^{0.01}$ \\
\hline & $\mathrm{RuCl}_{3}\left(\mathrm{H}_{2} \mathrm{O}\right)_{2} \mathrm{Gly}$ & 0.34 & 0.30 & $4 \mathrm{~d}^{6.70} 5 \mathrm{~s}^{0.27} 5 \mathrm{p}^{0.65} 5 \mathrm{~d}^{0.04} 6 \mathrm{p}^{0.01}$ & $4 \mathrm{~d}^{6.76} 5 \mathrm{~s}^{0.27} 5 \mathrm{p}^{0.63} 5 \mathrm{~d}^{0.03} 6 \mathrm{p}^{0.01}$ \\
\hline & $\mathrm{RuCl}_{3} \cdot 3 \mathrm{H}_{2} \mathrm{O}$ & 0.31 & 0.90 & $4 \mathrm{~d}^{6.71} 5 \mathrm{~s}^{0.27} 5 \mathrm{p}^{0.67} 5 \mathrm{~d}^{0.04} 6 \mathrm{p}^{0.01}$ & $4 \mathrm{~d}^{6.71} 5 \mathrm{~s}^{0.27} 5 \mathrm{p}^{0.67} 5 \mathrm{~d}^{0.04} 6 \mathrm{p}^{0.01}$ \\
\hline
\end{tabular}


complex for Wb97xd method. At B3lyp/Lanl2dz level for the $\mathrm{Ru}(\mathrm{III})$ complexes, we can see that $\mathrm{Ru}$ charge is high for NAMI, $\mathrm{RuCl}_{3}$ Terpy and $\mathrm{RuCl}_{3}\left(\mathrm{H}_{2} \mathrm{O}\right)_{3}$ with respectively $0.70,0.73$ and 0.90 . However, NAMI-A and $\mathrm{RuCl}_{3}\left(\mathrm{H}_{2} \mathrm{O}\right)_{2}$ Gly present low charges for $\mathrm{Ru}$ that are 0.54 and 0.30 respectively. These charges are lower than those of certain $\mathrm{Ru}(\mathrm{II})$ complexes such as $\mathrm{Ru}\left(\right.$ Azpy) ${ }_{3}^{2+}$ with 0.62 .

Regarding the electronic structure of $\mathrm{Ru}$, we recall that with the NBO program, there are the Lewis orbitals and the Rydberg orbitals. The occupied orbitals are known as Lewis' orbitals and the unoccupied ones are called Rydberg's orbitals. All the complexes show the same structure concerning both groups of molecules except for $\alpha-\mathrm{RuCl}_{2}(\mathrm{Azpy})_{2}$. Thus, this fact cannot also explain any difference between both groups of state. Therefore, let us investigate the state of the atomic orbital $d$ of the ruthenium in each complex. Table 2 displays the structure of the valence layer of $\mathrm{Ru}$ in the complexes calculated at Wb97xd/Lanl2dz level. The structure here regards only the Lewis atomic orbitals.

In octahedral metallic complexes, the structure of valence orbitals in the metal is usually of the type $(\mathrm{n}-1) d^{x} n s^{y} n p^{z}$ where $\mathrm{x}, \mathrm{y}$ and $\mathrm{z}$ stand for the numbers of electrons respectively for Atomic Orbitals $(\mathrm{AO}) d, s$ and $p$. The five atomic $d$ orbitals are degenerated in the isolated metal Ru. However, in a complex, according to the crystallin field theory, the five atomic orbitals are divided into two groups: $t_{2 g}$ spans $A O d_{x p}, d_{x z}$ and $d_{y z}$ with equal energy and $e_{g}$ comprises $d_{x^{2}-y^{2}}$ and

Table 2. Electronic structure of valence orbitals of ruthenium in the complex calculated at Wb97xd/Lanl2de level.

\begin{tabular}{|c|c|c|c|c|c|c|c|c|c|c|c|}
\hline Group & Complexes & & & Elec & tronic Stru & icture of $\mathrm{R}$ & & & & & Valence electrons \\
\hline \multirow{8}{*}{$\mathrm{Ru}(\mathrm{II})$} & \multirow{2}{*}{$\alpha-\mathrm{RuCl}_{2}(\mathrm{Azpy})_{2}$} & Structure & $\left(4 d_{x^{2}-y^{2}}\right)^{1.68}$ & $\left(4 d_{y z}\right)^{1.51}$ & $\left(4 \mathrm{~d}_{\mathrm{z}^{2}}\right)^{1.45}$ & $\left(4 d_{x z}\right)^{1.18}$ & $\left(4 d_{x y}\right)^{1.25}$ & $(5 s)^{0.27}$ & $\left(5 p_{x}\right)^{0.21}$ & $\left(5 p_{y}\right)^{0.20}\left(5 p_{z}\right)^{0.23}$ & \multirow{2}{*}{7.98} \\
\hline & & Energy & -0.29 & -0.27 & -0.25 & -0.22 & -0.23 & 0.34 & 0.35 & 0.35 & \\
\hline & \multirow{2}{*}{$\mathrm{Fac}-\mathrm{Ru}(\text { Azpy })_{3}^{2+}$} & Structure & $\left(4 d_{x^{2}-y^{2}}\right)^{1.41}$ & $\left(4 d_{y z}\right)^{1.20}$ & $\left(4 \mathrm{~d}_{z^{2}}\right)^{1.91}$ & $\left(4 d_{x z}\right)^{1.20}$ & $\left(4 \mathrm{~d}_{\mathrm{xy}}\right)^{1.41}$ & $(5 s)^{0.23}$ & $\left(5 p_{x}\right)^{0.16}$ & $\left(5 p_{y}\right)^{0.16}\left(5 p_{z}\right)^{0.12}$ & \multirow{2}{*}{7.81} \\
\hline & & Energy & -0.47 & -0.43 & -0.52 & -0.43 & -0.47 & 0.04 & 0.90 & 0.04 & \\
\hline & \multirow{2}{*}{$\operatorname{Mer}-\operatorname{Ru}(\text { Azpy })_{3}^{2+}$} & Structure & $\left(4 d_{x^{2}-y^{2}}\right)^{1.46}$ & $\left(4 d_{y z}\right)^{1.08}$ & $\left(4 \mathrm{~d}_{\mathrm{z}^{2}}\right)^{1.61}$ & $\left(4 d_{x z}\right)^{1.47}$ & $\left(4 \mathrm{~d}_{\mathrm{xy}}\right)^{1.53}$ & $(5 s)^{0.23}$ & $\left(5 p_{x}\right)^{0.17}$ & $\left(5 p_{y}\right)^{0.12}\left(5 p_{z}\right)^{0.15}$ & \multirow{2}{*}{7.81} \\
\hline & & Energy & -0.47 & -0.42 & -0.49 & -0.48 & -0.48 & 0.04 & 0.09 & 0.08 & \\
\hline & \multirow{2}{*}{$\mathrm{Ru}(\text { Bipy })_{3}^{2+}$} & Structure & $\left(4 d_{x^{2}-y^{2}}\right)^{1.44}$ & $\left(4 d_{y z}\right)^{1.18}$ & $\left(4 d_{z^{2}}\right)^{1.93}$ & $\left(4 d_{x z}\right)^{1.18}$ & $\left(4 d_{x y}\right)^{1.44}$ & $(5 s)^{0.18}$ & $\left(5 p_{x}\right)^{0.14}$ & $\left(5 p_{y}\right)^{0.14}\left(5 p_{z}\right)^{0.11}$ & \multirow{2}{*}{7.73} \\
\hline & & Energy & -0.43 & -0.39 & -0.48 & -0.39 & -0.43 & 0.18 & 0.13 & 0.08 & \\
\hline \multirow{10}{*}{$\mathrm{Ru}(\mathrm{III})$} & \multirow{2}{*}{ NAMI } & Structure & $\left(4 d_{x^{2}-y^{2}}\right)^{0.91}$ & $\left(4 d_{y z}\right)^{1.98}$ & $\left(4 \mathrm{~d}_{\mathrm{z}^{2}}\right)^{1.11}$ & $\left(4 d_{x z}\right)^{0.94}$ & $\left(4 d_{x y}\right)^{1.94}$ & $(5 s)^{0.29}$ & $\left(5 p_{x}\right)^{0.28}$ & $\left(5 p_{y}\right)^{0.20}\left(5 p_{z}\right)^{0.28}$ & \multirow{2}{*}{7.93} \\
\hline & & Energy & -0.05 & -0.19 & -0.09 & -0.08 & -0.18 & 0.48 & 0.50 & 0.53 & \\
\hline & \multirow{2}{*}{ NAMI-A } & Structure & $\left(4 \mathrm{~d}_{x^{2}-y^{2}}\right)^{0.97}$ & $\left(4 d_{y z}\right)^{1}$ & $\left(4 \mathrm{~d}_{\mathrm{z}^{2}}\right)^{1.14}$ & $\left(4 d_{x z}\right)^{1.94}$ & $\left(4 \mathrm{~d}_{\mathrm{xy}}\right)^{1.92}$ & $(5 s)^{0.32}$ & $\left(5 p_{x}\right)^{0.24}$ & $\left(5 p_{y}\right)^{0.30}\left(5 p_{z}\right)^{0.29}$ & \multirow{2}{*}{8.16} \\
\hline & & Energy & -0.10 & -0.12 & -0.13 & -0.22 & -0.23 & 0.34 & 0.43 & 0.49 & \\
\hline & \multirow{2}{*}{$\mathrm{RuCl}_{3}$ Terpy } & Structure & $\left(4 d_{x^{2}-y^{2}}\right)^{0.94}$ & $\left(4 \mathrm{~d}_{\mathrm{yz}}\right)^{1.2}$ & $\left(4 \mathrm{~d}_{\mathrm{z}^{2}}\right)^{0.91}$ & $\left(4 d_{x z}\right)^{1.91}$ & $\left(4 \mathrm{~d}_{\mathrm{xy}}\right)^{1.92}$ & $(5 s)^{0.28}$ & $\left(5 p_{x}\right)^{0.29}$ & $\left(5 p_{y}\right)^{0.19}\left(5 p_{z}\right)^{0.24}$ & \multirow{2}{*}{7.83} \\
\hline & & Energy & -0.20 & -0.25 & -0.22 & -0.33 & -0.33 & 0.4 & 0.39 & 0.28 & \\
\hline & \multirow{2}{*}{$\mathrm{RuCl}_{3}\left(\mathrm{H}_{2} \mathrm{O}\right)_{2} \mathrm{Gly}$} & Structure & $\left(4 \mathrm{~d}_{\mathrm{x}^{2}-\mathrm{y}^{2}}\right)^{0.92}$ & $\left(4 d_{y z}\right)^{1.72}$ & $\left(4 \mathrm{~d}_{\mathrm{z}^{2}}\right)^{1.25}$ & $\left(4 d_{x z}\right)^{1.06}$ & $\left(4 d_{x y}\right)^{1.75}$ & $(5 s)^{0.27}$ & $\left(5 p_{x}\right)^{0.22}$ & $\left(5 p_{y}\right)^{0.22}\left(5 p_{z}\right)^{0.20}$ & \multirow{2}{*}{7.62} \\
\hline & & Energy & -0.24 & -0.34 & -0.28 & -0.25 & -0.35 & 0.23 & 0.33 & 0.31 & \\
\hline & \multirow{2}{*}{$\mathrm{RuCl}_{3}\left(\mathrm{H}_{2} \mathrm{O}\right)_{3}$} & Structure & $\left(4 d_{x^{2}-y^{2}}\right)^{0.75}$ & $\left(4 \mathrm{~d}_{\mathrm{yz}}\right)^{1.23}$ & $\left(4 \mathrm{~d}_{\mathrm{z}^{2}}\right)^{0.80}$ & $\left(4 d_{x z}\right)^{1.96}$ & $\left(4 d_{x y}\right)^{1.98}$ & $(5 s)^{0.27}$ & $\left(5 p_{x}\right)^{0.26}$ & $\left(5 p_{y}\right)^{0.19}\left(5 p_{z}\right)^{0.22}$ & \multirow{2}{*}{7.65} \\
\hline & & Energy & -0.23 & -0.38 & -0.24 & -0.30 & -0.39 & 0.27 & 0.34 & 0.23 & \\
\hline
\end{tabular}


$d_{z}$ also degenerated as $d$ orbitals. One of these groups is assumed to theoretically contribute to the complex formation. In the case of octahedral complexes, $t_{2 g}$ is assumed to participate in the molecular orbitals [42]. In Table 2, according to $\mathrm{NBO}$ calculation, the structure of the valence orbital of $\mathrm{Ru}$ is $4 d^{x} 5 s^{y} 5 p^{z}$ and the five atomic orbitals in the subshell $d$ of Ru are $d_{x y}, d_{x z}, d_{y z}, d_{x^{2}-y^{2}}, d_{z^{2}}$ do not display the same energy nor are they divided in two groups. Therefore, they have not the equal number of electrons. Yet, in this study we can notice that the complexes are different regardless of their octahedral structures. Hens, each complex presents its own structure. Therefore, we can conclude that the state of Ru does not depend on the electronic structure of the $d$ orbitals. For instance, regarding the group $\mathrm{Ru}(\mathrm{II})$, while $4 d_{x^{2}-y^{2}}$ is the most stable in $\alpha-\mathrm{RuCl}_{2}(\mathrm{Azpy})_{2}$ it is replaced by $4 d_{z^{2}}$ in $\mathrm{Ru}(\text { Azpy })_{3}^{2+}$ and in $\mathrm{Ru}(\text { Bipy })_{3}^{2+}$. The particularity of these complexes is that all the five $d$ orbitals have the lowest energy. However in the $\mathrm{Ru}(\mathrm{III})$ group, we can see that they have high energy compared to the $\mathrm{Ru}(\mathrm{II})$ complexes. Also, the AOs $d$ are randomly involved in the formation of the molecular orbital with the ligands inasmuch as there are no longer degenerated. Besides, Table 3 displays the structure of the valence orbitals of $\mathrm{Ru}$ calculated at B3lyp/Lanl2dz level.

Table 3. Electronic structure of valence orbitals of ruthenium in the complex calculated at B3lyp/Lanl2dz level.

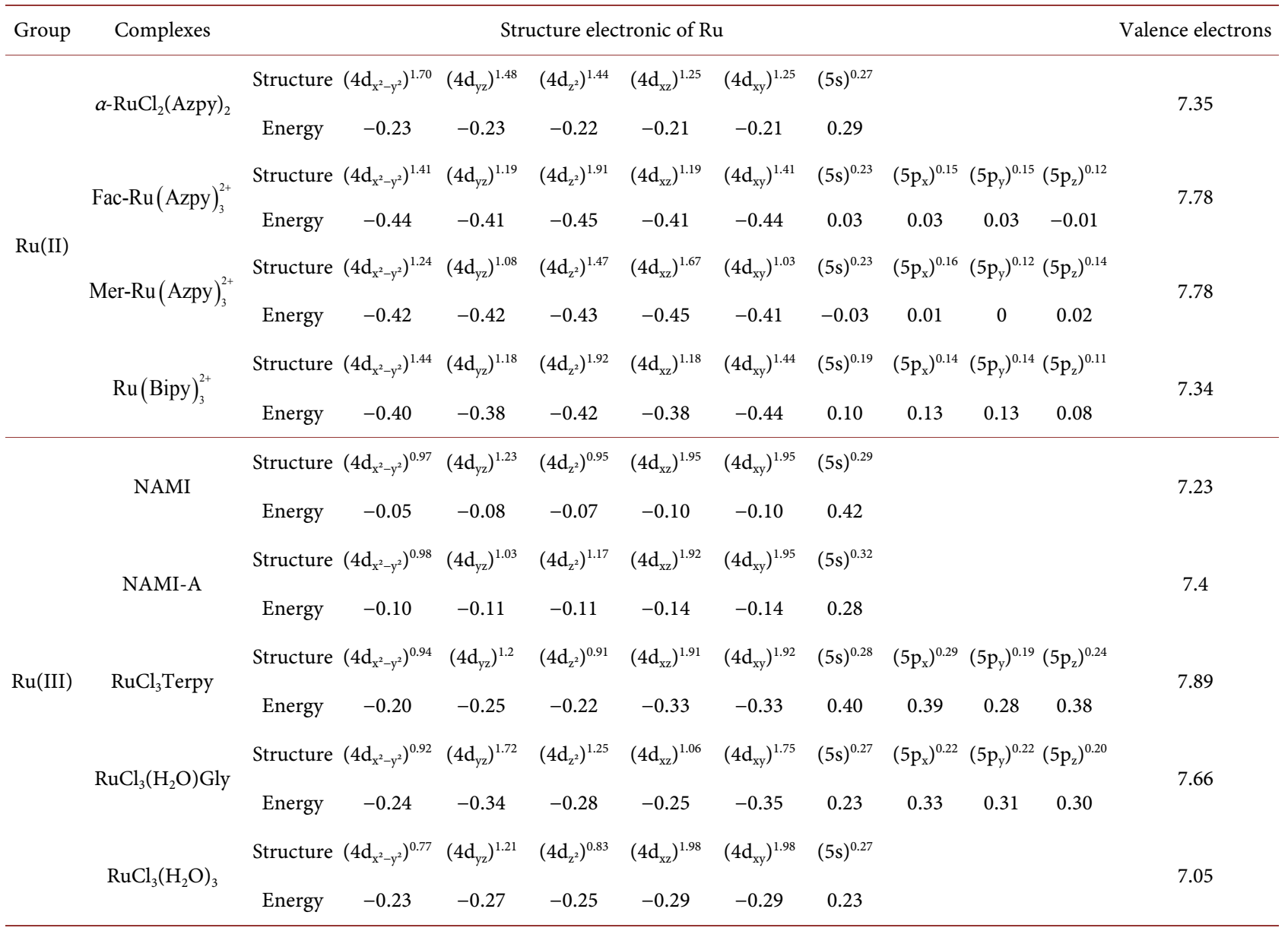


Table 3 shows that the structure of ruthenium's $d$ orbitals does not depend on the method used for calculation. In fact at B3lyp/Lanl2dz level, regarding the $\mathrm{Ru}$ (II) group, we can notice that the five $d$ orbitals have not the same energy and they don't also respect the crystallin field theory. Moreover, with the $\mathrm{Ru}(\mathrm{III})$ group, the same remark is made and the atomic orbitals of $\mathrm{Ru}$ are randomly involved in the complexes. Furthermore, no particular difference can be observed between both groups apart from the complexes of $\mathrm{Ru}(\mathrm{II})$ group seem to display lower energy. Table 4 displays the atomic orbitals $d$ of Ru classified after the remove of the degeneracy.

Table 4 shows that both functional describe the complexes almost the same way. This result shows the Jahn-Teller effect where $\alpha$ - $\mathrm{RuCl}_{2}$ (Azpy) $)_{2}$ undergo a compression as $4 d_{x^{2}-y^{2}}$ is more stable than $4 d_{z^{2}}$. However, all the other complexes irrespective of their state display a structure with elongation with the inversion of the stability between both orbitals [42]. Also, this statement cannot explain any difference between both groups $\mathrm{Ru}(\mathrm{II})$ and $\mathrm{Ru}(\mathrm{III})$. Moreover, Table 5 presents the reactivity parameters relative to frontier orbitals and the properties of the wavelength recorded at both B3lyp/Lanl2dz and Wb97xd/Lanl2dz levels.

Table 5 shows that the gap energy $\Delta \mathrm{E}_{\mathrm{H}-\mathrm{L}}$ displays no difference between the

Table 4. Classification of $d$ Atomic Orbitals of Ru after removing the degeneracy.

\begin{tabular}{|c|c|c|c|c|}
\hline \multirow{2}{*}{ Group } & \multirow{2}{*}{ Complexes } & \multirow{2}{*}{ functional } & \multicolumn{2}{|c|}{ Molecular $d$ orbitals } \\
\hline & & & $t_{2 g}$ & $e_{g}$ \\
\hline \multirow{8}{*}{$\mathrm{Ru}(\mathrm{II})$} & \multirow{2}{*}{$\alpha-\mathrm{RuCl}_{2}(\mathrm{Azpy})_{2}$} & Wb97xd & $4 \mathrm{~d}_{\mathrm{yz}}<4 \mathrm{~d}_{\mathrm{xy}}<4 \mathrm{~d}_{\mathrm{xz}}$ & $4 d_{x^{2}-y^{2}}<4 d_{x^{2}}$ \\
\hline & & B3lyp & $4 \mathrm{~d}_{\mathrm{yz}}<4 \mathrm{~d}_{\mathrm{xy}}=4 \mathrm{~d}_{\mathrm{xz}}$ & $4 \mathrm{~d}_{\mathrm{x}^{2}-\mathrm{y}^{2}}<4 \mathrm{~d}_{\mathrm{x}^{2}}$ \\
\hline & \multirow{2}{*}{ Fac-Ru $(\text { Azpy })_{3}^{2+}$} & Wb97xd & $4 \mathrm{~d}_{\mathrm{yz}}=4 \mathrm{~d}_{\mathrm{xz}}>4 \mathrm{~d}_{\mathrm{xy}}$ & $4 \mathrm{~d}_{\mathrm{x}^{2}}<4 \mathrm{~d}_{\mathrm{x}^{2}-\mathrm{y}^{2}}$ \\
\hline & & B3lyp & $4 \mathrm{~d}_{\mathrm{yz}}=4 \mathrm{~d}_{\mathrm{xz}}>4 \mathrm{~d}_{\mathrm{xy}}$ & $4 d_{x^{2}}<4 d_{x^{2}-y^{2}}$ \\
\hline & \multirow{2}{*}{$\operatorname{Mer}-R u(\text { Azpy })_{3}^{2+}$} & Wb97xd & $4 \mathrm{~d}_{\mathrm{yz}}>4 \mathrm{~d}_{\mathrm{xz}}=4 \mathrm{~d}_{\mathrm{xy}}$ & $4 \mathrm{~d}_{\mathrm{x}^{2}}<4 \mathrm{~d}_{\mathrm{x}^{2}-\mathrm{y}^{2}}$ \\
\hline & & B3lyp & $4 \mathrm{~d}_{\mathrm{xz}}<4 \mathrm{~d}_{\mathrm{yz}}<4 \mathrm{~d}_{\mathrm{xy}}$ & $4 \mathrm{~d}_{\mathrm{x}^{2}}<4 \mathrm{~d}_{\mathrm{x}^{2}-\mathrm{y}^{2}}$ \\
\hline & \multirow{2}{*}{$\mathrm{Ru}(\text { Bipy })_{3}^{2+}$} & Wb97xd & $4 \mathrm{~d}_{\mathrm{xy}}<4 \mathrm{~d}_{\mathrm{xz}}=4 \mathrm{~d}_{\mathrm{yz}}$ & $4 \mathrm{~d}_{\mathrm{x}^{2}}<4 \mathrm{~d}_{\mathrm{x}^{2}-\mathrm{y}^{2}}$ \\
\hline & & B3lyp & $4 \mathrm{~d}_{\mathrm{xy}}<4 \mathrm{~d}_{\mathrm{xz}}=4 \mathrm{~d}_{\mathrm{yz}}$ & $4 \mathrm{~d}_{\mathrm{x}^{2}}<4 \mathrm{~d}_{\mathrm{x}^{2}-\mathrm{y}^{2}}$ \\
\hline \multirow{10}{*}{$\mathrm{Ru}(\mathrm{III})$} & \multirow{2}{*}{ NAMI } & Wb97xd & $4 \mathrm{~d}_{\mathrm{yz}}<4 \mathrm{~d}_{\mathrm{xy}}<4 \mathrm{~d}_{\mathrm{xz}}$ & $4 d_{x^{2}}<4 d_{x^{2}-y^{2}}$ \\
\hline & & B3lyp & $4 \mathrm{~d}_{\mathrm{xy}}=4 \mathrm{~d}_{\mathrm{xz}}<4 \mathrm{~d}_{\mathrm{yz}}$ & $4 \mathrm{~d}_{\mathrm{x}^{2}}<4 \mathrm{~d}_{\mathrm{x}^{2}-\mathrm{y}^{2}}$ \\
\hline & \multirow{2}{*}{ NAMI-A } & Wb97xd & $4 \mathrm{~d}_{\mathrm{xy}}<4 \mathrm{~d}_{\mathrm{xz}}<4 \mathrm{~d}_{\mathrm{yz}}$ & $4 \mathrm{dx}^{2}<4 \mathrm{~d}_{\mathrm{x}^{2}-\mathrm{y}^{2}}$ \\
\hline & & B3lyp & $4 \mathrm{~d}_{\mathrm{xy}}=4 \mathrm{~d}_{\mathrm{xz}}<4 \mathrm{~d}_{\mathrm{yz}}$ & $4 \mathrm{~d}_{\mathrm{x}^{2}}<4 \mathrm{~d}_{\mathrm{x}^{2}-\mathrm{y}^{2}}$ \\
\hline & \multirow{2}{*}{$\mathrm{RuCl}_{3}$ Terpy } & Wb97xd & $4 \mathrm{~d}_{\mathrm{xy}}=4 \mathrm{~d}_{\mathrm{xz}}<4 \mathrm{~d}_{\mathrm{yz}}$ & $4 \mathrm{~d}_{\mathrm{x}^{2}}<4 \mathrm{~d}_{\mathrm{x}^{2}-\mathrm{y}^{2}}$ \\
\hline & & B3lyp & $4 \mathrm{~d}_{\mathrm{xy}}=4 \mathrm{~d}_{\mathrm{xz}}<4 \mathrm{~d}_{\mathrm{yz}}$ & $4 \mathrm{~d}_{\mathrm{x}^{2}}<4 \mathrm{~d}_{\mathrm{x}^{2}-\mathrm{y}^{2}}$ \\
\hline & \multirow{2}{*}{$\mathrm{RuCl}_{3}\left(\mathrm{H}_{2} \mathrm{O}\right)_{2} \mathrm{Gly}$} & Wb97xd & $4 \mathrm{~d}_{\mathrm{xy}}<4 \mathrm{~d}_{\mathrm{yz}}<4 \mathrm{~d}_{\mathrm{xz}}$ & $4 \mathrm{~d}_{\mathrm{x}^{2}}<4 \mathrm{~d}_{\mathrm{x}^{2}-\mathrm{y}^{2}}$ \\
\hline & & B3lyp & $4 \mathrm{~d}_{\mathrm{xy}}<4 \mathrm{~d}_{\mathrm{yz}}<4 \mathrm{~d}_{\mathrm{xz}}$ & $4 \mathrm{dx}^{2}<4 \mathrm{~d}_{\mathrm{x}^{2}-\mathrm{y}^{2}}$ \\
\hline & \multirow{2}{*}{$\mathrm{RuCl}_{3}\left(\mathrm{H}_{2} \mathrm{O}\right)_{3}$} & Wb97xd & $4 \mathrm{~d}_{\mathrm{xy}}<4 \mathrm{~d}_{\mathrm{yz}}<4 \mathrm{~d}_{\mathrm{xz}}$ & $4 \mathrm{~d}_{\mathrm{x}^{2}}<4 \mathrm{~d}_{\mathrm{x}^{2}-\mathrm{y}^{2}}$ \\
\hline & & B3lyp & $4 \mathrm{~d}_{\mathrm{xy}}=4 \mathrm{~d}_{\mathrm{yz}}<4 \mathrm{~d}_{\mathrm{xz}}$ & $4 \mathrm{~d}_{\mathrm{x}^{2}}<4 \mathrm{~d}_{\mathrm{x}^{2}-\mathrm{y}^{2}}$ \\
\hline
\end{tabular}


Table 5. Reactivity parameters with frontier orbitals and absorption properties of $\mathrm{Ru}(\mathrm{II})$ and $\mathrm{Ru}(\mathrm{III})$ complexes calculated at both $\mathrm{Wb} 97 \mathrm{xd} / \mathrm{Lanl} 2 \mathrm{dz}$ and B3lyp/Lanl2dz levels, the properties of the wavelength and its corresponding energy and the frequency.

\begin{tabular}{|c|c|c|c|c|c|c|c|c|c|c|c|c|}
\hline \multirow[b]{3}{*}{ Complexes } & \multicolumn{6}{|c|}{ Wb97xd } & \multicolumn{6}{|c|}{ B3lyp } \\
\hline & \multicolumn{3}{|c|}{ Composition of frontier orbitals } & \multirow[b]{2}{*}{$\Delta \mathrm{E}(\mathrm{ev})$} & \multirow[b]{2}{*}{$\lambda_{\max }(\mathrm{nm})$} & \multirow[b]{2}{*}{$f\left(s^{-1}\right)$} & \multicolumn{3}{|c|}{ Composition of frontier orbitals } & \multirow[b]{2}{*}{$\Delta \mathrm{E}(\mathrm{ev})$} & \multirow[b]{2}{*}{$\lambda_{\max }(\mathrm{nm})$} & \multirow[b]{2}{*}{$f\left(s^{-1}\right)$} \\
\hline & $\begin{array}{c}\text { HOMO } \\
(\mathrm{eV})\end{array}$ & $\begin{array}{l}\text { LUMO } \\
(\mathrm{eV})\end{array}$ & $\Delta \mathrm{E}_{\mathrm{H}-\mathrm{L}}(\mathrm{eV})$ & & & & $\begin{array}{c}\text { HOMO } \\
(\mathrm{eV})\end{array}$ & $\begin{array}{c}\text { LUMO } \\
(\mathrm{eV})\end{array}$ & $\Delta \mathrm{E}_{\mathrm{H}-\mathrm{L}}(\mathrm{eV})$ & & & \\
\hline$\alpha-\mathrm{RuCl}_{2}(\text { Azpy })_{2}$ & -7.48 & -1.65 & 5.83 & 2.31 & 536.41 & 0.11 & -5.55 & -3.33 & 2.22 & 1.93 & 640.44 & 0.06 \\
\hline Fac-Ru(Azpy $)_{3}^{2+}$ & -13.76 & -7.15 & 6.61 & 2.65 & 467.01 & 0.02 & -11.76 & -8.89 & 2.87 & 3.04 & 407.50 & 0.02 \\
\hline $\operatorname{Mer}-\operatorname{Ru}(\text { Azpy })_{3}^{2+}$ & -13.78 & -7.25 & 6.53 & 3.44 & 360.36 & 0.24 & -11.76 & -8.96 & 2.80 & 2.64 & 469.15 & 0.05 \\
\hline $\mathrm{Ru}(\text { Bipy })_{3}^{2+}$ & -12.98 & -5.86 & 7.12 & 3.46 & 358.49 & 0.15 & -11.08 & -7.70 & 3.37 & 2.89 & 429.44 & 0.11 \\
\hline NAMI & -4.25 & 3.58 & 7.83 & 2.92 & 424.81 & 0.02 & -1.77 & 0.79 & 2.56 & 2.57 & 481.69 & 0.02 \\
\hline NAMI-A & -5.03 & 2.85 & 7.88 & 2.74 & 452.16 & 0.02 & -2.58 & 0.00 & 2.58 & 2.39 & 518.56 & 0.02 \\
\hline $\mathrm{RuCl}_{3}$ Terpy & -7.43 & -1.60 & 5.83 & 2.38 & 521.35 & 0.01 & -5.40 & -3.68 & 1.72 & 1.99 & 624.06 & 0.03 \\
\hline $\mathrm{RuCl}_{3}\left(\mathrm{H}_{2} \mathrm{O}\right)_{2} \mathrm{Gly}$ & -8.57 & -1.79 & 6.78 & 3.02 & 409.65 & 0.02 & -6.31 & -3.67 & 2.64 & 3.04 & 407.50 & 0.02 \\
\hline $\mathrm{RuCl}_{3}\left(\mathrm{H}_{2} \mathrm{O}\right)_{3}$ & -8.42 & -2.30 & 6.12 & 3.01 & 411.89 & 0.01 & -6.30 & -3.86 & 2.44 & 2.24 & 551.30 & 0.01 \\
\hline
\end{tabular}

$\mathrm{Ru}(\mathrm{II})$ and $\mathrm{Ru}(\mathrm{III})$ complexes both with B3lyp/Lan2dz and wb97xd/Lanl2dz levels. At wb97xd/Lanl2dz level we can see that $\mathrm{RuCl}_{3}$ Terpy and $\alpha$-Rucl $(\text { azpy })_{2}$ have the smallest values regarding the gap energy. Moreover, both isomers $\operatorname{Mer}-\operatorname{Ru}(\text { Azpy })_{3}^{2+}$ and $\mathrm{Fac}-\mathrm{Ru}(\text { Azpy })_{3}^{2+}$ have almost the same gap energy regardless the difference in their geometrical structure. Furthermore, the same remark is observed at B3lyp/Lan2dz level. Among all the complexes, the $\mathrm{Ru}(\mathrm{III})$ compound $\mathrm{RuCl}_{3}$ Terpy is the most reactive with $1.72 \mathrm{eV}$ as gap energy followed by $\mathrm{Ru}(\mathrm{II})$ complex $\alpha-\mathrm{Rucl}_{2}(\text { azpy })_{2}$ with $2.22 \mathrm{eV}$. Thus, we can assume that the energy gap cannot make any real difference between $\mathrm{Ru}$ (II) and $\mathrm{Ru}$ (III) complexes regarding their reactivities. Besides both molecules, the third most reactive complex at both levels is the originate $\mathrm{RuCl}_{3}\left(\mathrm{H}_{2} \mathrm{O}\right)_{3}$. This fact shows that the reactivity of $\mathrm{Ru}$ is the most effective when the ligands are Azpy and Terpy in presence of $\mathrm{Cl}$ atoms.

Regarding the absorption properties, we can see again that only $\mathrm{RuCl}_{3}$ Terpy and $\alpha$ - $\operatorname{Rucl}_{2}(\text { azpy })_{2}$ present wavelengths in the visible domain up to $500 \mathrm{~nm}$. This data is characteristic of MLCT transfer [43]. They present respectively 521.35 $\mathrm{nm}$ and $624.06 \mathrm{~nm}$ at $\mathrm{Wb} 97 \mathrm{xd} /$ Lanl2dz level and $536.41 \mathrm{~nm}$ and $640.44 \mathrm{~nm}$ at B3lyp/Lanl2dz level. Moreover, they require the least energies to perform these metals to ligand charge transfer transitions. Basically, B3lyp offers all the complexes to be active in visible domain regardless the state of the metal.

Figure 6 displays the energetic diagram of the $\mathrm{Ru}$ complexes recorded at $\mathrm{Wb} 97 \mathrm{xd} / \mathrm{Lanl} 2 \mathrm{dz}$ level. We can notice that the energy of the frontier orbitals increases with the number of chloride atom of the structure. And comparatively to the energy of the HOMO of the DNA (-2.08) [44] that is assumed to provide electron to the complex sensitizer, $\mathrm{Ru}(\mathrm{III})$ complexes are found effectively more capable of binding to the target. Regarding NAMI and NAMI-A, Even if they 


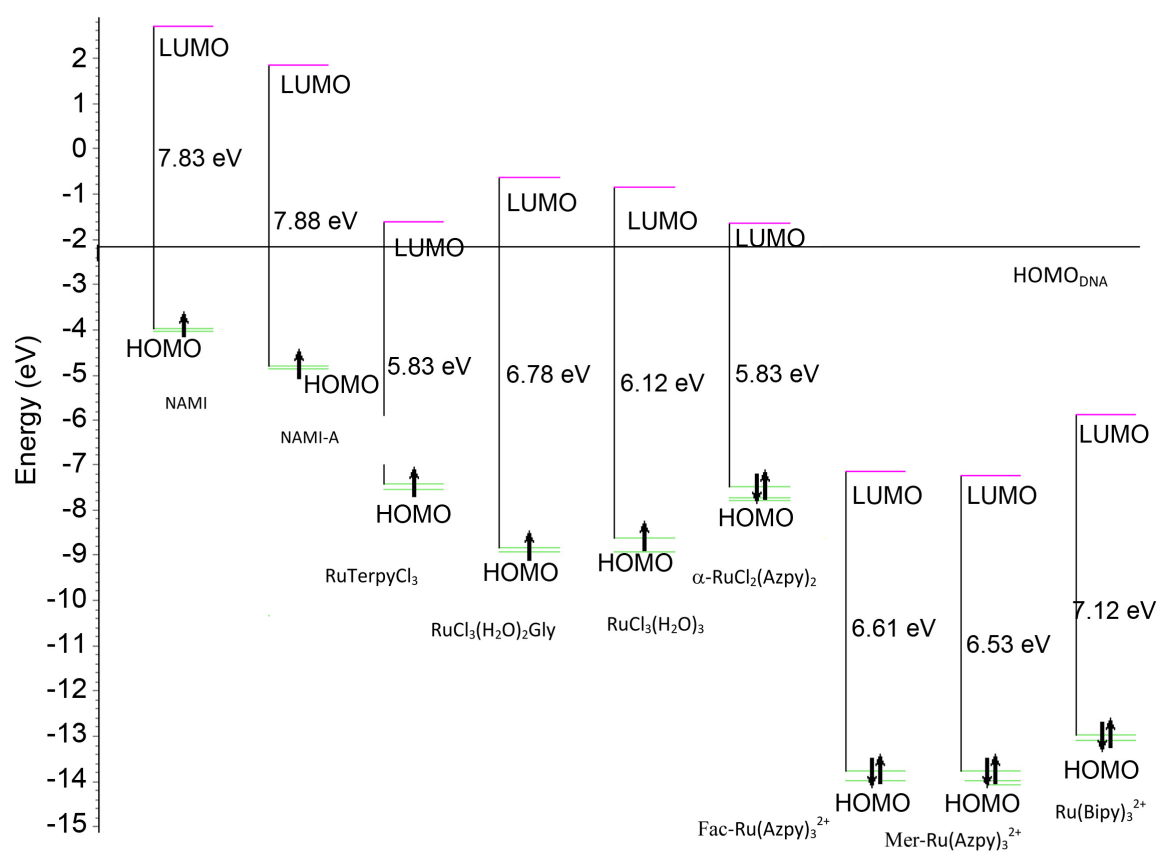

Figure 6. Energetic diagramm of $\mathrm{Ru}$ complexes calculated at wb97xd/Lanl2dz level. Comparatively to the energy HOMO of the DNA we can effectively see that only $\mathrm{Ru}$ (III) complexes are likely available to link to the DNA.

have their LUMO orbitalsrelatively higher than the HOMO of the DNA, they nevertheless are less efficient comparatively to the other $\mathrm{Ru}(\mathrm{III})$ complexes' LUMO. We can assume that this is certainly due to the presence of four chloride atoms. Concerning the $\mathrm{Ru}(\mathrm{II})$ complexes, $\alpha-\mathrm{RuCl}_{2}(\mathrm{Azpy})_{2}$ presents the most active LUMO that can react with the cancer molecule thereby confirming its activity as cytotoxic molecule [45]. Regarding the cation molecules such as $\operatorname{Mer}-\operatorname{Ru}(\text { Azpy })_{3}^{2+}, \operatorname{Fac}-\operatorname{Ru}(\text { Azpy })_{3}^{2+}$ and $\operatorname{Ru}(\text { Bipy })_{3}^{2+}$, they have the lowest energy concerning both their HOMO and LUMO orbitals. However, they are far from reacting with DNA as receivers of electron. Their cytotoxicity must certainly be explained by other mechanisms.

When we consider B3lyp/Lanl2dz level, we can notice the same order of energy of the frontier orbitals of the complexes. Regarding the energy of the LUMO orbitals, they are classified according to the following order: $\mathrm{LUMO}_{\mathrm{NAMI}}>$ $\mathrm{LUMO}_{\text {NAMI-A }}>\mathrm{LUMO}_{\alpha-\mathrm{RuCl}_{2}(\mathrm{Azpy})_{2}}>\mathrm{LUMO}_{\mathrm{RuCl}_{3}\left(\mathrm{H}_{2} \mathrm{O}\right)_{2} \mathrm{Gly}}>\mathrm{LUMO}_{\mathrm{RuCl}_{3}(\text { Terpy })}>$ $\mathrm{LUMO}_{\mathrm{RuCl}_{3}\left(\mathrm{H}_{2} \mathrm{O}\right)_{2}}>\mathrm{LUMO}_{\mathrm{Ru}(\mathrm{Bipy})_{3}^{2+}}>\mathrm{LUMO}_{\mathrm{Fac}-\mathrm{Ru}(\mathrm{Azpy})_{3}^{2+}}>\mathrm{LUMO}_{\mathrm{Mer}-\mathrm{Ru}(\mathrm{Azpy})_{3}^{2+}}$. Herein, Figure 3 displays the energy diagram of $\mathrm{Ru}$ complexes performed à B3lyp/Lanl2dz.

Figure 7 shows that $\mathrm{Fac}-\mathrm{Ru}(\mathrm{Azpy})_{3}^{2+}$ and $\mathrm{Mer}-\mathrm{Ru}(\mathrm{Azpy})_{3}^{2+}$ have almost the same energy regarding both the HOMO and the LUMO. Yet, $\operatorname{Mer}-\operatorname{Ru}(\text { Azpy })_{3}^{2+}$ is assumed to be active cytotoxically and $\mathrm{Fac}-\mathrm{Ru}(\text { Azpy })_{3}^{2+}$ is however inactive. The difference between both complexes may certainly roots in relation of the complexes. Besides, Table 6 displays the structure of the frontier orbitals. 


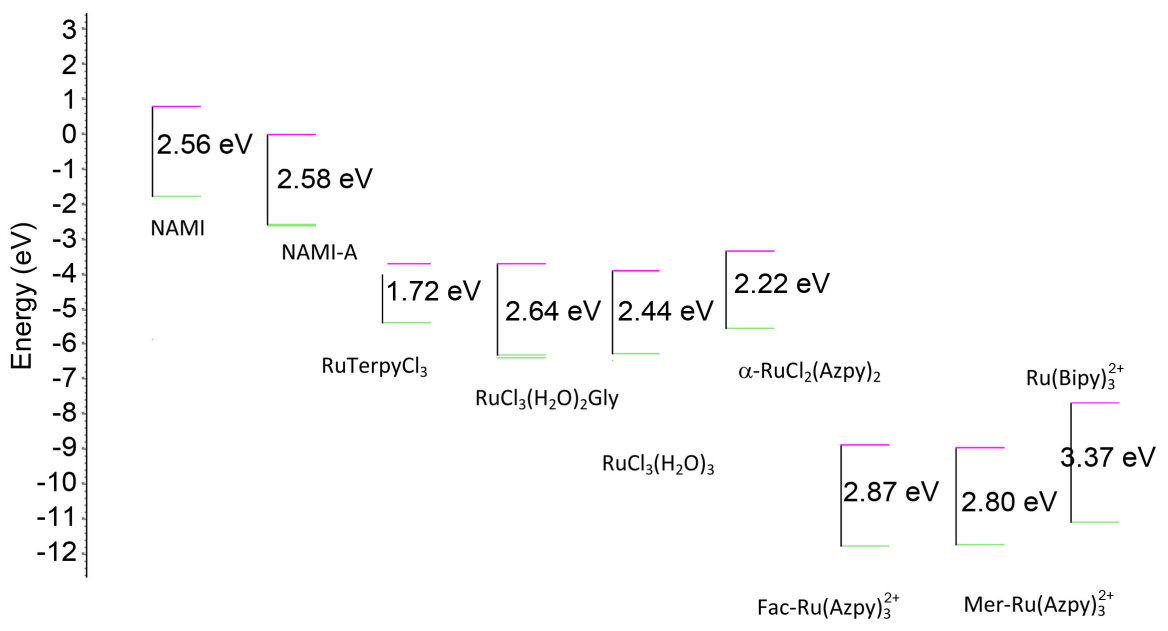

Figure 7. Energy diagram of Ru complexes calculated at B3lyp/Lanl2dz level.

Table 6. Frontier orbitals and their compositions calculated at Wb97xd/Lanl2dz and B3lyp/Lanl2dz levels.

\begin{tabular}{|c|c|c|c|}
\hline \multirow{2}{*}{ Complexes } & \multirow{2}{*}{ Frontier Orbitals } & \multicolumn{2}{|c|}{ Composition of frontier orbitals } \\
\hline & & wb97xd & b3lyp \\
\hline \multirow{2}{*}{$\alpha-\mathrm{RuCl}_{2}(\text { Azpy })_{2}$} & HOMO & Ru (45\%) Cl (34\%) Azpy (20\%) & Ru (46\%) Cl (34\%) Azpy (20\%) \\
\hline & LUMO & $\mathrm{Ru}(8 \%) \mathrm{Cl}(1 \%)$ Azpy (91\%) & $\mathrm{Ru}(11 \%) \mathrm{Cl}(2 \%)$ Azpy (87\%) \\
\hline \multirow{2}{*}{$\operatorname{Mer}-\operatorname{Ru}(\text { Azpy })_{3}^{2+}$} & HOMO & Ru (37\%) Azpy (63\%) & Ru (50\%) Azpy (50\%) \\
\hline & LUMO & Ru (2\%) Azpy (98\%) & Ru (2\%) Azpy (98\%) \\
\hline \multirow{2}{*}{$\operatorname{Mer}-\operatorname{Ru}(\text { Azpy })_{3}^{2+}$} & HOMO & Ru (46\%) Azpy (54\%) & Ru (57\%) Azpy (43\%) \\
\hline & LUMO & Ru (3\%) Azpy (97\%) & Ru (3\%) Azpy (97\%) \\
\hline \multirow{2}{*}{$\mathrm{Ru}(\text { Bipy })_{3}^{2+}$} & HOMO & Ru (79\%) Azpy (21\%) & Ru (78\%) Azpy (22\%) \\
\hline & LUMO & $\mathrm{Ru}(0 \%)$ Azpy (100\%) & Ru (0\%) Azpy (100\%) \\
\hline \multirow{2}{*}{ NAMI } & HOMO & $\mathrm{Ru}(66 \%) \mathrm{Cl}(26 \%)$ Imi (8\%) & $\mathrm{Ru}(65 \%) \mathrm{Cl}(1 \%) \operatorname{Imi}(34 \%)$ \\
\hline & LUMO & $\mathrm{Ru}(81 \%) \mathrm{Cl}(18 \%) \operatorname{Imi}(1 \%)$ & $\mathrm{Ru}(80 \%) \mathrm{Cl}(0 \%) \operatorname{Imi}(20 \%)$ \\
\hline \multirow{2}{*}{ NAMI-A } & HOMO & $\mathrm{Ru}(52 \%) \mathrm{Cl}(43 \%)$ Imi+DMSO (4\%) & $\mathrm{Ru}(57 \%) \mathrm{Cl}(37 \%)$ Imi+DMSO (6\%) \\
\hline & LUMO & $\mathrm{Ru}(78 \%) \mathrm{Cl}(20 \%)$ Imi+DMSO (2\%) & $\mathrm{Ru}(78 \%) \mathrm{Cl}(21 \%)$ Imi+DMSO (1\%) \\
\hline \multirow{2}{*}{$\mathrm{RuCl}_{3}$ Terpy } & HOMO & $\mathrm{Ru}(19 \%) \mathrm{Cl}(77 \%)$ Terpy (5\%) & $\mathrm{Ru}(49 \%) \mathrm{Cl}(39 \%)$ Terpy (12\%) \\
\hline & LUMO & $\mathrm{Ru}(0 \%) \mathrm{Cl}(69 \%)$ Terpy (31\%) & $\mathrm{Ru}(53 \%) \mathrm{Cl}(15 \%)$ Terpy (32\%) \\
\hline \multirow{2}{*}{$\mathrm{RuCl}_{3}\left(\mathrm{H}_{2} \mathrm{O}\right)_{2} \mathrm{Gly}$} & HOMO & $\mathrm{Ru}(51 \%) \mathrm{Cl}(42 \%)$ Gly (5\%) $\mathrm{H}_{2} \mathrm{O}(2 \%)$ & $\mathrm{Ru}(65 \%) \mathrm{Cl}(27 \%)$ Gly (5\%) $\mathrm{H}_{2} \mathrm{O}(3 \%)$ \\
\hline & LUMO & $\mathrm{Ru}(52 \%) \mathrm{Cl}(18 \%)$ Gly (23\%) $\mathrm{H}_{2} \mathrm{O}(7 \%)$ & $\mathrm{Ru}(76 \%) \mathrm{Cl}(12 \%)$ Gly $(10 \%) \mathrm{H}_{2} \mathrm{O}(2 \%)$ \\
\hline \multirow{2}{*}{$\mathrm{RuCl}_{3}\left(\mathrm{H}_{2} \mathrm{O}\right)_{3}$} & HOMO & $\mathrm{Ru}(48 \%) \mathrm{Cl}(51 \%) \mathrm{H}_{2} \mathrm{O}(1 \%)$ & $\mathrm{Ru}(66 \%) \mathrm{Cl}(27 \%) \mathrm{H}_{2} \mathrm{O}(7 \%)$ \\
\hline & LUMO & $\mathrm{Ru}(60 \%) \mathrm{Cl}(14 \%) \mathrm{H}_{2} \mathrm{O}(26 \%)$ & $\mathrm{Ru}(76 \%) \mathrm{Cl}(20 \%) \mathrm{H}_{2} \mathrm{O}(4 \%)$ \\
\hline
\end{tabular}

When we consider the groups of molecules involved in the structure of frontier orbitals through Table 6, we can notice that the HOMO orbitals are mainly represented by orbitals of $\mathrm{Ru}$ in all the complexes. However, regarding the LUMO orbitals for $\mathrm{Ru}$ (II) complexes, we notice in this case that Ru does not intervene in the orbital both with Wb97xd and B3lyp functionals. Here again we 
cannot see any difference that can explain the inability for $\mathrm{Fac}-\mathrm{Ru}(\mathrm{Azpy})_{3}^{2+}$ to react as therapy molecular agent comparatively with $\operatorname{Mer}-\operatorname{Ru}(\text { Azpy })_{3}^{2+}$. Therefore, let us study the photophysical properties of the complexes.

\subsection{TDDFT Analysis of the Complexes}

\subsubsection{Singlet Excited States}

Table 7 displays the lowest singlets of $\mathrm{Ru}(\mathrm{II})$ and $\mathrm{Ru}(\mathrm{III})$ calculated at B3lyp/Lanl2dz level.

Table 7. Lowest singlets and triplets calculated at B3lyp/Lanl2dz of $\mathrm{Ru}(\mathrm{II})$ and $\mathrm{Ru}(\mathrm{III})$ complexes. It displays their energy (eV) the wavelength (nm) and the oscillator strength (f).

\begin{tabular}{|c|c|c|c|c|c|c|c|c|c|c|c|c|c|}
\hline \multirow{2}{*}{ Complexes } & \multicolumn{11}{|c|}{ B3lyp } & \multirow[b]{2}{*}{ T5 } & \multirow[b]{2}{*}{ T6 } \\
\hline & & S1 & S2 & S3 & S4 & S5 & S6 & $\mathrm{T} 1$ & $\mathrm{~T} 2$ & T3 & $\mathrm{T} 4$ & & \\
\hline \multirow{3}{*}{$\alpha-\mathrm{RuCl}_{2}(\mathrm{Azpy})_{2}$} & $\mathrm{E}$ & 1.68 & 1.72 & 1.93 & 2.24 & 2.25 & 2.92 & 0.98 & 1.28 & 1.33 & 1.85 & 2.28 & 2.51 \\
\hline & $\lambda$ & 738.6 & 720.07 & 640.44 & 552.11 & 550.42 & 424.37 & 1266.44 & 969.77 & 932.99 & 669.28 & 543.44 & 494.38 \\
\hline & $\mathrm{f}$ & 0.003 & 0.003 & 0.056 & 0.018 & 0.024 & 0.070 & 0 & 0 & 0 & 0 & 0 & 0 \\
\hline \multirow{3}{*}{$\mathrm{Fac}-\mathrm{Ru}(\mathrm{Azpy})_{3}^{2+}$} & $\mathrm{E}$ & 2.05 & 2.06 & 2.49 & 2.63 & 2.68 & 2.75 & 0.08 & 0.48 & 0.55 & 0.58 & 1.04 & 1.12 \\
\hline & $\lambda$ & 603.48 & 603.15 & 497.02 & 471.44 & 462.64 & 451 & 14542.3 & 2582.04 & 2252.6 & 2152.17 & 1186.20 & 1104.08 \\
\hline & $\mathrm{f}$ & 0.002 & 0.006 & 0.008 & 0.016 & 0.035 & 0.031 & 0.001 & 0.009 & 0.006 & 0.008 & 0.002 & 0.001 \\
\hline \multirow{3}{*}{$\operatorname{Mer}-\operatorname{Ru}(\text { Azpy })_{3}^{2+}$} & $\mathrm{E}$ & 1.92 & 1.98 & 2.08 & 2.38 & 2.55 & 2.64 & 1.53 & 1.59 & 1.95 & 2.08 & 2.23 & 2.29 \\
\hline & $\lambda$ & 645.02 & 625.91 & 595.32 & 519.73 & 486.71 & 469.15 & 811.30 & 777.0 & 634.39 & 597.18 & 555.34 & 540.64 \\
\hline & $\mathrm{f}$ & 0.004 & 0.002 & 0.004 & 0.002 & 0.041 & 0.052 & 0 & 0 & 0 & 0 & 0 & 0 \\
\hline \multirow{3}{*}{$\mathrm{Ru}(\text { Bipy })_{3}^{2+}$} & $\mathrm{E}$ & 2.53 & 2.74 & 2.89 & 3.37 & 3.57 & 3.77 & 2.34 & 2.40 & 2.52 & 2.67 & 3.17 & 3.18 \\
\hline & $\lambda$ & 489.43 & 451.87 & 429.44 & 367.46 & 347.28 & 329.23 & 528.83 & 516.08 & 491.87 & 469.01 & 464.85 & 389.8 \\
\hline & $\mathrm{f}$ & 0.001 & 0.007 & 0.11 & 0.008 & 0.006 & 0.015 & 0 & 0 & 0 & 0 & 0 & 0 \\
\hline \multirow{3}{*}{ NAMI } & $\mathrm{E}$ & 2.573 & 3.55 & 3.65 & 3.76 & 3.79 & 3.91 & 2.57 & 2.64 & 2.74 & 2.85 & 3.55 & 3.76 \\
\hline & $\lambda$ & 481.72 & 349.09 & 339.76 & 329.86 & 326.91 & 317.45 & 481.72 & 469.68 & 451.93 & 428.9 & 349.09 & 329.86 \\
\hline & $\mathrm{f}$ & 0.017 & 0.002 & 0 & 0.002 & 0.006 & 0.001 & 0.017 & 0 & 0 & 0 & 0.002 & 0.002 \\
\hline \multirow{3}{*}{ NAMI-A } & $\mathrm{E}$ & 2.02 & 2.39 & 2.43 & 2.46 & 2.67 & 2.83 & 2.02 & 2.44 & 2.44 & 3.35 & 3.47 & 3.51 \\
\hline & $\lambda$ & 612.53 & 518.56 & 508.78 & 503.05 & 4614.91 & 438.43 & 612.49 & 518.49 & 508.69 & 369.67 & 357.36 & 353.48 \\
\hline & $\mathrm{f}$ & 0.001 & 0.016 & 0.014 & 0.000 & 0.001 & 0.000 & 0.001 & 0.016 & 0.014 & 0.004 & 0.001 & 0.001 \\
\hline \multirow{3}{*}{$\mathrm{RuCl}_{3}$ Terpy } & $\mathrm{E}$ & 1.47 & 1.794 & 1.85 & 1.98 & 2.00 & 2.43 & 1.47 & 1.79 & 1.83 & 1.85 & 1.99 & 2.01 \\
\hline & $\lambda$ & 840.52 & 691.07 & 670.62 & 624.06 & 618.18 & 509.25 & 840.52 & 691.07 & 677.76 & 670.62 & 624.06 & 618.18 \\
\hline & $\mathrm{f}$ & 0.002 & 0.005 & 0.002 & 0.027 & 0.011 & 0.013 & 0.002 & 0.005 & 0.004 & 0.002 & 0.027 & 0.011 \\
\hline \multirow{3}{*}{$\mathrm{RuCl}_{3}\left(\mathrm{H}_{2} \mathrm{O}\right)_{2} \mathrm{Gly}$} & $\mathrm{E}$ & 2.59 & 2.64 & 2.69 & 2.74 & 2.78 & 3.04 & 2.63 & 2.69 & 2.74 & 2.80 & 3.10 & 4.05 \\
\hline & $\lambda$ & 478.97 & 469.28 & 460.81 & 452.5 & 446.29 & 407.50 & 471.98 & 461.63 & 452.52 & 443.33 & 400.29 & 305.90 \\
\hline & $\mathrm{f}$ & 0.003 & 0.009 & 0.002 & 0.003 & 0.002 & 0.016 & 0.002 & 0.011 & 0.002 & 0.003 & 0.017 & 0.001 \\
\hline \multirow{3}{*}{$\mathrm{RuCl}_{3}\left(\mathrm{H}_{2} \mathrm{O}\right)_{3}$} & $\mathrm{E}$ & 2.26 & 2.66 & 2.69 & 2.82 & 3.404 & 3.81 & 2.26 & 2.66 & 2.69 & 2.82 & 3.40 & 3.81 \\
\hline & $\lambda$ & 549.1 & 466.37 & 460.73 & 439.69 & 364.17 & 325.61 & 549.10 & 466.37 & 460.73 & 439.69 & 364.17 & 325.61 \\
\hline & $\mathrm{f}$ & 0.012 & 0.005 & 0.003 & 0.002 & 0.002 & 0.008 & 0.012 & 0.005 & 0.003 & 0.002 & 0.002 & 0.008 \\
\hline
\end{tabular}


We can see in Table 7 that almost all the $\mathrm{Ru}(\mathrm{II})$ complexes present their first wavelengths higher than $600 \mathrm{~nm}$ thereby indication the capacity to behave as photo therapy agent. In fact, they wavelengths are situated in the therapeutic window [46]. However, only $\mathrm{Ru}(\text { Bipy })_{3}^{2+}$ presents $489.43 \mathrm{~nm}$ suitable for shallow surface diseases [47].

Regarding the $\mathrm{Ru}(\mathrm{III})$ molecules, NAMI and $\mathrm{RuCl}_{3}\left(\mathrm{H}_{2} \mathrm{O}\right)_{2}$ Gly are active only for superficial diseases with respectively $481.72 \mathrm{~nm}$ and $478.97 \mathrm{~nm}$. However, NAMI-A, $\mathrm{RuCl}_{3}$ Terpy with $\mathrm{RuCl}_{3}\left(\mathrm{H}_{2} \mathrm{O}\right)_{3}$ show their ability to act against deeply localized cancers.

\subsubsection{Triplets Excited States}

This is the most important state for the complexes since its lifetime is very longer than the singlet's lifetime [48]. And it is responsible for the photosensitized reactions [49]. Table 7 displays the six lowest excited triplet states. We can notice that the lowest energy $\mathrm{T} 1\left(\mathrm{E}_{\mathrm{T} 1}\right)$ shows a value of a frequency different from zero apart from the case of $\alpha-\mathrm{RuCl}_{2}(\text { Azpy })_{2}, \operatorname{Mer}-\mathrm{Ru}(\text { Azpy })_{3}^{2+}$ and $\mathrm{Ru}(\mathrm{Bipy})_{3}^{2+}$. These molecules belong all to the family of $\mathrm{Ru}(\mathrm{II})$. It results from this statement that those three complexes cannot generate a $\mathrm{T}$ state. Therefore, they cannot be used for photodynamic therapy. However, Fac-Ru(Azpy) $)_{3}^{2+}$ that is reported to not display any cytotoxic activity appears the lone to show an excited state with $0.085 \mathrm{eV}$ as $\mathrm{E}_{\mathrm{T} 1}$ and its wavelength at $14,542.30 \mathrm{~nm}$. Regarding the $\mathrm{Ru}(\mathrm{III})$ complexes, we can see that all of them display $\mathrm{T}$ energies with high frequency. Therefore, they can well be used as PDT agents. Then, our investigation will concern only these $\mathrm{Ru}(\mathrm{III})$ complexes and Fac-Ru(Azpy $)_{3}^{2+}$. Thus, let's determine the vertical electron affinity and vertical potential ionization both at ground and excited states.

\subsubsection{Vertical Electron Affinity (VEA) and Vertical Ionization Potential (VIP)}

Table 8 and Table 9 display the vertical electron affinity (VEA) and vertical ionization potential (VIP) both at ground state $\mathrm{S}_{0}$ and excited T1 state. There are assumed to be respectively at the origin of electron donation and electron acceptance in reactions. We can see for both levels of calculus that $\mathrm{VEA}_{\mathrm{S} 0}$ is negative for all the complexes except for NAMI-A. Therefore, the coming work will be performed only with B3lyp/Lanl2dz. Here, NAMI appears to be the most ionizable complex with the lowest $\operatorname{VIP}_{\mathrm{S} 0}(0.15$ hartree $)$ followed by NAMI-A. the complexes without chloride atoms are the least ionizable. It may indicate that the strength of ionization depends on the numbers of chloride atoms in the structure. Concerning $\mathrm{VEA}_{\mathrm{s} 0}$, it shows that the molecules most able to accept electrons are the cations. And the anions with four chloride atoms namely NAMI and NAMI-A are the least acceptors. Besides, both Fac-Ru(Azpy $)_{3}^{2+}$ and $\operatorname{Mer}-\mathrm{Ru}(\text { Azpy })_{3}^{2+}$ don't show any difference.

Moreover, Table 8 displays the vertical electronic affinity and vertical ionization potential in the excited state $\mathrm{T}_{1}$ for the Ru complexes. As we said before that $\alpha-\mathrm{RuCl}_{2}(\text { Azpy })_{2}, \quad \mathrm{Mer}-\mathrm{Ru}(\mathrm{Azpy})_{3}^{2+}$ and $\mathrm{Ru}(\mathrm{Bipy})_{3}^{2+}$ do not show any triplet 
Table 8. Vertical electronic affinity and vertical ionization potential recorded at ground state $\mathrm{S}_{0}$ both at B3lyp/Lanl2dz and $\mathrm{Wb} 97 \mathrm{xd} /$ Lanl2dz levels. $\mathrm{E}_{\mathrm{p}}, \mathrm{E}_{\mathrm{a}}$ and $\mathrm{E}_{\mathrm{c}}$ are calculated in hartree.

\begin{tabular}{|c|c|c|c|c|c|c|c|c|c|c|}
\hline \multirow{2}{*}{ Complexes } & \multicolumn{5}{|c|}{ Wb97xd } & \multicolumn{5}{|c|}{ B3lyp } \\
\hline & $\mathrm{E}_{\mathrm{p}}$ & $\mathrm{E}_{\mathrm{a}}$ & $\mathrm{E}_{\mathrm{c}}$ & ${ }^{\mathrm{a}} \mathrm{VEA}_{\mathrm{SO}}$ & ${ }^{b} \mathrm{VIP}_{\mathrm{S} 0}$ & $\mathrm{E}_{\mathrm{p}}$ & $\mathrm{E}_{\mathrm{a}}$ & $\mathrm{E}_{\mathrm{c}}$ & ${ }^{\mathrm{a}} \mathrm{VEA}_{\mathrm{S} 0}$ & ${ }^{\mathrm{b}} \mathrm{VIP}_{\mathrm{S} 0}$ \\
\hline$\alpha-\mathrm{RuCl}_{2}(\mathrm{Azpy})_{2}$ & -1300.99 & -1301.08 & -1300.74 & -0.08 & 0.25 & -1301.40 & -1301.46 & -1301.14 & -0.08 & 0.24 \\
\hline Fac-Ru $(\text { Azpy })_{3}^{2+}$ & -1859.08 & -1859.36 & -1858.61 & -0.28 & 0.47 & -1859.70 & -1859.96 & -1859.21 & -0.29 & 0.47 \\
\hline $\operatorname{Mer}-\operatorname{Ru}(\text { Azpy })_{3}^{2+}$ & -1859.08 & -1859.36 & -1858.61 & -0.28 & 0.48 & -1859.70 & -1859.96 & -1859.21 & -0.29 & 0.47 \\
\hline $\mathrm{Ru}(\text { Bipy })_{3}^{2+}$ & -1579.03 & -1579.25 & -1578.59 & -0.22 & 0.44 & -1579.50 & -1579.76 & -1579.07 & -0.24 & 0.44 \\
\hline NAMI & -606.21 & -606.26 & -605.89 & -0.04 & 0.33 & -606.34 & -606.259 & -606.195 & 0.08 & 0.15 \\
\hline NAMI-A & -545.09 & -545.04 & -544.56 & 0.05 & 0.53 & -545.19 & -545.138 & -545.02 & 0.05 & 0.17 \\
\hline $\mathrm{RuCl}_{3}$ Terpy & -881.02 & -881.12 & -880.73 & -0.09 & 0.30 & -881.26 & -881.353 & -880.97 & -0.09 & 0.29 \\
\hline $\mathrm{RuCl}_{3}\left(\mathrm{H}_{2} \mathrm{O}\right)_{2} \mathrm{Gly}$ & -576.02 & -576.09 & -575.64 & -0.08 & 0.38 & -576.14 & -576.212 & -575.82 & -0.07 & 0.32 \\
\hline $\mathrm{RuCl}_{3}\left(\mathrm{H}_{2} \mathrm{O}\right)_{3}$ & -368.09 & -368.16 & -367.71 & -0.08 & 0.38 & -368.15 & -368.21 & -367.83 & -0.06 & 0.33 \\
\hline
\end{tabular}

${ }^{\mathrm{a}} \mathrm{VEA}_{\mathrm{SO}}=\mathrm{E}_{\mathrm{a}}-\mathrm{E}_{\mathrm{p}} \cdot{ }^{\mathrm{b}} \mathrm{VIP}_{\mathrm{S0}}=\mathrm{E}_{\mathrm{c}}-\mathrm{E}_{\mathrm{p}}$.

Table 9. Excitation energies of the lowest triplets $\left(\mathrm{E}_{\mathrm{T} 1} \mathrm{in} \mathrm{eV}\right)$, vertical electron affinities (VEA in $\left.\mathrm{eV}\right)$ and vertical ionization potentials (VIP in eV) of Ru complexes in vacuum.

\begin{tabular}{|c|c|c|c|c|c|}
\hline \multirow{2}{*}{ Complexes } & \multicolumn{5}{|c|}{ B3lyp } \\
\hline & $\mathrm{VEA}_{\mathrm{so}}$ & $\mathrm{VIP}_{\mathrm{S} 0}$ & $\mathrm{E}_{\mathrm{T} 1}$ & ${ }^{\mathrm{a}} \mathrm{VAE}_{\mathrm{T1}}$ & ${ }^{\mathrm{b}} \mathrm{VIP}_{\mathrm{T} 1}$ \\
\hline$\alpha-\mathrm{RuCl}_{2}(\mathrm{Azpy})_{2}$ & -0.08 & 0.245 & 0 & - & - \\
\hline Fac-Ru(Azpy $)_{3}^{2+}$ & -0.29 & 0.467 & 0.085 & -0.373 & 0.382 \\
\hline $\operatorname{Mer}-\operatorname{Ru}(\text { Azpy })_{3}^{2+}$ & -0.29 & 0.466 & 0 & - & - \\
\hline $\mathrm{Ru}(\text { Bipy })_{3}^{2+}$ & -0.24 & 0.443 & 0 & - & - \\
\hline NAMI & 0.083 & 0.147 & 2.574 & -2.491 & -2.427 \\
\hline NAMI-A & 0.055 & 0.173 & 2.024 & -1.969 & -1.851 \\
\hline $\mathrm{RuCl}_{3}$ Terpy & -0.09 & 0.293 & 1.475 & -1.568 & -1.182 \\
\hline $\mathrm{RuCl}_{3}\left(\mathrm{H}_{2} \mathrm{O}\right)_{2} \mathrm{Gly}$ & -0.07 & 0.319 & 2.627 & -2.696 & -2.308 \\
\hline $\mathrm{RuCl}_{3}\left(\mathrm{H}_{2} \mathrm{O}\right)_{3}$ & -0.06 & 0.327 & 2.26 & -2.317 & -1.933 \\
\hline
\end{tabular}

${ }^{\mathrm{a}} \mathrm{VEA}_{\mathrm{T} 1}=\mathrm{VEA}_{\mathrm{S} 0}-\mathrm{E}_{\mathrm{T} 1} ;{ }^{\mathrm{b}} \mathrm{VIP}_{\mathrm{T} 1}=\mathrm{VIP}_{\mathrm{S} 0}-\mathrm{E}_{\mathrm{T} 1}$.

state, they therefore are assumed not to be active photo dynamically. So, we will analyze the $\mathrm{Ru}(\mathrm{III})$ molecules and $\mathrm{Fac}-\mathrm{Ru}(\mathrm{Azpy})_{3}^{2+}$ in so far that they show energy values at triplet state. $\mathrm{VEA}_{\mathrm{T} 1}$ and $\mathrm{VIP}_{\mathrm{T} 1}$ designate respectively the ability to receive and to donate an electron at the excited triplet state. In Table 8, we can see that $\mathrm{Fac}-\mathrm{Ru}(\text { Azpy })_{3}^{2+}$ is the most ionizable molecule with $\operatorname{VIP}_{\mathrm{T} 1}=$ 0.382 a.u. conversely, $\mathrm{RuCl}_{3}\left(\mathrm{H}_{2} \mathrm{O}\right)_{2} \mathrm{Gly}$ is the most able to receive electron at excited state as it shows the smallest value of $\mathrm{VEA}_{\mathrm{T} 1}$.

\subsection{Study of Photosensitization Capacity of Ru Complexes}

The objective here is to find out the mechanism of the reaction of the photosensitized complex with the DNA or the RNA bases which are responsible for the 
damage of the cell. Two mechanisms known as I and II are hitherto admitted in literature [50]. Through mechanism I, the complex is said to act directly on the DNA or RNA base that is assumed to donate the electron. Also, this reaction $s$ assumed to take place in an area without oxygen molecule. In this case, the complex must be either in its excited state or as a cation. In our previous article, we calculated the VIP $\mathrm{V}_{\mathrm{S} 0}$ and $\mathrm{VEA}_{\mathrm{S} 0}$ of the DNA and RNA base and they are displayed in Table 10 [49]. Regarding the mechanism II, it is performed in presence of a triplet ${ }^{3} \mathrm{O}_{2}$ that will be excited into singlet ${ }^{1} \mathrm{O}_{2}$, responsible for DNA or RNA damage.

\subsubsection{Mechanism I}

It was admitted that Guanine and Uracil are respectively the most donor and acceptor of electron. It means that those bases must be the targets of the complex in the cell-free of oxygen. Therefore, the prediction of the mechanism must be performed only with both molecules. The reactions concerned by the mechanism I are expressed by the following equations. These equations resume two pathways.

$$
\begin{gathered}
{[\mathrm{Ru}-\mathrm{K}]\left(\mathrm{T}_{1}\right)+\mathrm{B} \rightarrow[\mathrm{Ru}-\mathrm{K}]^{--}+\mathrm{B}^{++}} \\
{[\mathrm{Ru}-\mathrm{K}]\left(\mathrm{T}_{1}\right)+[\mathrm{Ru}-\mathrm{K}]\left(\mathrm{S}_{0}\right) \rightarrow[\mathrm{Ru}-\mathrm{K}]^{--}+[\mathrm{Ru}-\mathrm{K}]^{++}} \\
{[\mathrm{Ru}-\mathrm{K}]\left(\mathrm{T}_{1}\right)+[\mathrm{Ru}-\mathrm{K}]\left(\mathrm{T}_{1}\right) \rightarrow[\mathrm{Ru}-\mathrm{K}]^{+-}+[\mathrm{Ru}-\mathrm{K}]^{+}} \\
{[\mathrm{Ru}-\mathrm{K}]^{++}+\mathrm{B} \rightarrow[\mathrm{Ru}-\mathrm{K}]\left(\mathrm{S}_{0}\right)+\mathrm{B}^{++}}
\end{gathered}
$$

Equation (1) indicates that $\mathrm{Ru}$ complex $(\mathrm{Ru}-\mathrm{K})$ being in its excited state $\mathrm{T}_{1}$ will extract electron from the DNA base. This reaction will be governed by $\mathrm{VEA}_{\mathrm{T} 1}$ of Ru-K and VIP of the DNA base and the sum of both data must be negative to consider the reaction as thermodynamically feasible.

Secondly, a radical cation of Ru-K performed through Equations (2) and (3) can also receive electron from the DNA base. That reaction is expressed by Equation (4). Equation (2) is also expressed by sum either $\operatorname{VEA}_{\mathrm{T} 1}+\mathrm{VIP}_{\mathrm{S} 0}$ or $\mathrm{VIP}_{\mathrm{T} 1}+$ $\mathrm{VEA}_{\mathrm{S} 0}$ of Ru-K . whereas Equation (3) is governed by the sum VEA $\mathrm{VA}_{\mathrm{T} 1}+\mathrm{VIP}_{\mathrm{T} 1}$.

Table 11 shows that Equation (1) is positive for Fac-Ru(Azpy) ${ }_{3}^{2+}$ and all the $\mathrm{Ru}$ (III) complexes. It indicates that the DNA or RNA cells cannot react directly

Table 10. Vertical ionization potential and vertical electronic affinity of DNA and RNA bases performed at B3lyp/Lanl2dz level.

\begin{tabular}{ccc}
\hline DNA or RNA & $\mathrm{VIP}_{\mathrm{so}}(\mathrm{a} . \mathrm{u})$ & $\mathrm{VEA}_{\mathrm{s0}}(\mathrm{a} . \mathrm{u})$ \\
\hline Adenine & 8.19 & 0.67 \\
Cytosine & 8.74 & 0.42 \\
Guanine & 7.91 & 0.61 \\
Thymine & 8.84 & 0.11 \\
Uracil & 9.3 & 0.01 \\
\hline
\end{tabular}


Table 11. Sum of the $\mathrm{VEA}_{\mathrm{T1}}$ parameters of the complex and VIP parameters of the Guanine reflecting the interactions according to Equation (1), Sum $\mathrm{VEA}_{\mathrm{T} 1}+\mathrm{VIP}_{\mathrm{S} 0}$ or $\mathrm{VIP}_{\mathrm{T} 1}+\mathrm{VEA}_{\mathrm{S} 0}$ both reflecting the auto ionization reaction and $\mathrm{VIP}_{\mathrm{T} 1}+\mathrm{VEA}_{\mathrm{T} 1}$, all performed at B3lyp/Lanl2dz level.

\begin{tabular}{|c|c|c|c|c|c|c|c|c|c|}
\hline \multirow{2}{*}{ Complexes } & \multicolumn{9}{|c|}{ B3lyp } \\
\hline & $\mathrm{VEA}_{\mathrm{S} 0}$ & $\mathrm{VIP}_{\mathrm{S} 0}$ & $\mathrm{E}_{\mathrm{T} 1}$ & $\mathrm{VAE}_{\mathrm{T} 1}$ & $\mathrm{VIP}_{\mathrm{T} 1}$ & $\mathrm{VEA}_{\mathrm{T} 1}(\mathrm{C})+\operatorname{VIP}(\mathrm{G})$ & $\mathrm{VEA}_{\mathrm{T} 1}+\mathrm{VIP}_{\mathrm{S} 0}$ & $\mathrm{VIP}_{\mathrm{T} 1}+\mathrm{VEA}_{\mathrm{S} 0}$ & $\mathrm{VIP}_{\mathrm{T} 1}+\mathrm{VEA}_{\mathrm{T} 1}$ \\
\hline$\alpha-\mathrm{RuCl}_{2}(\mathrm{Azpy})_{2}$ & -0.08 & 0.24 & 0 & - & - & - & - & - & - \\
\hline Fac-Ru $(\text { Azpy })_{3}^{2+}$ & -0.29 & 0.47 & 0.08 & -0.37 & 0.38 & 7.54 & 0.09 & 0.09 & 0.01 \\
\hline $\operatorname{Mer}-\operatorname{Ru}(\text { Azpy })_{3}^{2+}$ & -0.29 & 0.47 & 0 & - & - & - & - & - & - \\
\hline $\mathrm{Ru}(\text { Bipy })_{3}^{2+}$ & -0.24 & 0.44 & 0 & - & - & - & - & - & - \\
\hline NAMI & 0.08 & 0.15 & 2.57 & -2.49 & -2.43 & 5.42 & -2.34 & -2.34 & -4.92 \\
\hline NAMI-A & 0.05 & 0.17 & 2.02 & -1.97 & -1.85 & 5.94 & -1.80 & -1.80 & -3.82 \\
\hline $\mathrm{RuCl}_{3}$ Terpy & -0.09 & 0.29 & 1.47 & -1.57 & -1.18 & 6.34 & -1.27 & -1.27 & -2.75 \\
\hline $\mathrm{RuCl}_{3}\left(\mathrm{H}_{2} \mathrm{O}\right)_{2} \mathrm{Gly}$ & -0.07 & 0.32 & 2.63 & -2.70 & -2.31 & 5.21 & -2.38 & -2.38 & -5.00 \\
\hline $\mathrm{RuCl}_{3}\left(\mathrm{H}_{2} \mathrm{O}\right)_{3}$ & -0.06 & 0.33 & 2.26 & -2.32 & -1.93 & 5.59 & -1.99 & -1.99 & -4.25 \\
\hline
\end{tabular}

on the complexes since the sum of vertical electronic affinity of the complexes and the potential ionized vertical of the cells are positive. Whereas the auto ionization Equations (2) and (3), the Fac-Ru(Azpy) $)_{3}^{2+}$ still show positive value indicating its impossibility to react without oxygen as photo dynamic therapy agent directly over DNA or RNA molecules. Even the cationic formation of $\mathrm{Fac}-\mathrm{Ru}(\mathrm{Azpy})_{3}^{2+}$ shows the positive value. We can conclude that the $\mathrm{Ru}(\mathrm{II})$ complex cannot react on DNA or RNA by the reaction type I.

Regarding all $\mathrm{Ru}(\mathrm{III})$ complexes, we can notice that they all are active through the auto-ionization process both through Equation (2) and Equation (3). We can therefore assume that the reaction type I is allowed for the $\mathrm{Ru}(\mathrm{III})$ complexes only if they are radical cations $[\mathrm{Ru}-\mathrm{K}]^{++}$.

\subsubsection{Mechanism II}

In this case, the Ru complex must be in excited triplet state. And we can have two reactions: The first reaction regards the $\mathrm{Ru}$ complex in an excited state where, it will transfer energy to the triplet oxygen (in its fundamental state) allowing it to become a singlet molecule according to Equation (5). The singlet oxygen owing to its strength is therefore responsible for the damage of all anormal molecules in its environment [51].

$$
[\mathrm{Ru}-\mathrm{K}]\left(\mathrm{T}_{1}\right)+{ }^{3} \mathrm{O}_{2} \rightarrow[\mathrm{Ru}-\mathrm{K}]\left(\mathrm{S}_{0}\right)+{ }^{1} \mathrm{O}_{2}
$$

Besides, Equation (5) requires that the energy necessary to excite the complex must be higher than the energy admitted for oxygen to pass from ground state to its excited state. According to literature, the energy necessary to excite ${ }^{3} \mathrm{O}_{2}$ is 1.06 $\mathrm{eV}$ [52] [53]. Furthermore, all the $\mathrm{Ru}(\mathrm{III})$ complexes display an $\mathrm{E}_{\mathrm{T} 1}$ according to Table 11 higher than this energy thereby concluding their ability to excite the oxygen triplet. However, Fac- $\mathrm{Ru}(\text { Azpy })_{3}^{2+}$ shows $0.08 \mathrm{eV}$ as $\mathrm{E}_{\mathrm{T} 1}$ energy. Thus, we can also assume that the $\mathrm{Ru}$ (II) complex cannot generate ${ }^{1} \mathrm{O}_{2}$ molecule. 
Table 12. Sum of VIP ${ }_{\mathrm{T} 1}$ of Ru complex and $\mathrm{AEA}\left(\mathrm{O}_{2}\right)$ of oxygen in $\mathrm{eV}$.

\begin{tabular}{cccc}
\hline & \multicolumn{3}{c}{ B3lyp } \\
\cline { 2 - 4 } Complexes & $\mathrm{VIP}_{\mathrm{T} 1}$ & $\mathrm{AEA}\left(\mathrm{O}_{2}\right)$ & $\mathrm{VIP}_{\mathrm{T} 1}+\mathrm{AEA}\left(\mathrm{O}_{2}\right)$ \\
\hline$\alpha-\mathrm{RuCl}_{2}(\text { Azpy })_{2}$ & - & - \\
$\mathrm{Fac}-\mathrm{Ru}(\text { Azpy })_{3}^{2+}$ & 0.38 & -0.21 \\
$\mathrm{Mer}-\mathrm{Ru}(\mathrm{Azpy})_{3}^{2+}$ & - & - \\
$\mathrm{Ru}(\mathrm{Bipy})_{3}^{2+}$ & - & -0.59 & -3.02 \\
$\mathrm{NAMI}$ & -2.43 & -2.44 \\
$\mathrm{NAMI}^{2+}$ & -1.85 & & -1.77 \\
$\mathrm{RuCl}_{3} \mathrm{Terpy}$ & -1.18 & -2.90 \\
$\mathrm{RuCl}_{3}\left(\mathrm{H}_{2} \mathrm{O}\right)_{2} \mathrm{Gly}$ & -2.31 & -2.52 \\
$\mathrm{RuCl}_{3}\left(\mathrm{H}_{2} \mathrm{O}\right)_{3}$ & -1.93 & & - \\
\hline
\end{tabular}

The second reaction regards a transfer of electron from $\mathrm{Ru}$ complex to ${ }^{3} \mathrm{O}_{2}$ to generate a superoxide radical anion $\mathrm{O}_{2}^{--}$through Equation (6).

$$
[\mathrm{Ru}-\mathrm{K}]\left(\mathrm{T}_{1}\right)+{ }^{3} \mathrm{O}_{2} \rightarrow[\mathrm{Ru}-\mathrm{K}]^{++}+\mathrm{O}_{2}^{--}
$$

The condition to perform this reaction requires that the sum of the vertical ionization potential at the triplet state $\operatorname{VIP}_{\mathrm{T} 1}$ of the complex and the adiabatic affinity of oxygen $\operatorname{AEA}\left(\mathrm{O}_{2}\right)$ must be negative. And the $\operatorname{AEA}\left(\mathrm{O}_{2}\right)$ in vacuum is assumed to be $-0.59 \mathrm{eV}$ [46] [54]. Table 12 shows the sum of $\mathrm{VIP}_{\mathrm{T} 1}$ of $\mathrm{Ru}$ complex and $\operatorname{AEA}\left(\mathrm{O}_{2}\right)$.

All the values in Table 12 regarding the sum $\operatorname{VIP}_{\mathrm{T} 1}+\mathrm{AEA}\left(\mathrm{O}_{2}\right)$ are negative indicating that $\mathrm{Ru}$ complexes can generate the radical superoxide anion. Even here, $\mathrm{Fac}-\mathrm{Ru}(\mathrm{Azpy})_{3}^{2+}$ allows this reaction but with difficulty comparatively to $\mathrm{Ru}$ (III) complexes. We can conclude in the mechanism II that Fac-Ru(Azpy) $)_{3}^{2+}$ is active only when it concerns the transfer of electron to ${ }^{3} \mathrm{O}_{2}$ to generate $\mathrm{O}_{2}^{--}$. Whereas $\mathrm{Ru}(\mathrm{III})$ complexes in general, they can be used as photodynamic agent regardless the nature of the mechanism.

\section{Conclusions}

We have been comparing the reactivity of $\mathrm{Ru}(\mathrm{II})$ and $\mathrm{Ru}(\mathrm{III})$ complexes through their oxidation state in this paper. We used the DFT method and both functional B3lyp and Wb97xd with the pseudopotential Lanl2dz for this investigation. Both groups of $\mathrm{Ru}$ molecules comprise $\alpha$ - $\mathrm{RuCl}_{2}(\mathrm{Azpy})_{2}$, Fac-Ru(Azpy $)_{3}^{2+}$, $\operatorname{Mer}-\mathrm{Ru}(\text { Azpy })_{3}^{2+}$ and $\mathrm{Ru}(\mathrm{Bipy})_{3}^{2+}$ for the group $\mathrm{Ru}(\mathrm{II})$ and NAMI, NAMI-A, $\mathrm{RuCl}_{3}$ Terpy, $\mathrm{RuCl}_{3}\left(\mathrm{H}_{2} \mathrm{O}\right)_{2}$ Gly and $\mathrm{RuCl}_{3}\left(\mathrm{H}_{2} \mathrm{O}\right)_{3}$ for the group $\mathrm{Ru}(\mathrm{III})$. All these molecules except $\operatorname{RuCl}_{3}\left(\mathrm{H}_{2} \mathrm{O}\right)_{3}$ are assumed to be therapeutic agents at their fundamental state. Moreover, they don't seem to show any difference regarding the electronic structure of the ruthenium atom irrespective of their oxidation state. In addition, the analysis of the Ru five $d$ orbitals of the complexes shows that they undergo the Jahn-Teller effect that doesn't affect their therapeutic ac- 
tivity. Only the structure of $\alpha-\mathrm{RuCl}_{2}(\mathrm{Azpy})_{2}$ is discovered different from the others. Besides, regarding their frontier orbitals, they show that the cations display the lowest energy and the energy is increasing with the number of chloride atoms. Also, $\mathrm{RuCl}_{3}$ terpy and $\alpha$ - $\mathrm{RuCl}_{2}(\mathrm{Azpy})_{2}$, display the lowest LUMO energy suitable for DNA and RNA binding without excitation however they belong to different groups. Hence, there is no real difference between both groups.

When it comes to the PDT activity, the TD-DFT method was performed to determine vertical electron affinity and vertical ionization potential both at the ground and excited states. This calculus shows that $\mathrm{Ru}(\mathrm{II})$ complexes are inactive due certainly to their singlet state where valence electrons are coupled. However, Fac-Ru(Azpy $)_{3}^{2+}$ that is assumed not to be active over DNA or RNA cells at fundamental state is the lone $\mathrm{Ru}(\mathrm{II})$ complex able to display the exciting T1 state. Maybe due to the ligand Azpy or its C3 symmetry. Yet, this complex does not form a cation by auto-ionization. And it hardly reacts only over oxygen to generate superoxide radical anion.

Whereas $\mathrm{Ru}$ (III) complexes are active both at fundamental and excited states in the presence or lack of oxygen. In the latter state, they can react through auto-ionization to generate a cationic complex without oxygen, or they can generate the radical superoxide $\mathrm{O}_{2}^{--}$. All these forms can destroy the affected DNA cells. We can retain that the ability for $\mathrm{Ru}(\mathrm{III})$ complexes to react better than $\mathrm{Ru}$ (II) complexes is certainly due to the presence of the non-coupled electron that does not require much energy to move up to a high shell within $\mathrm{Ru}(\mathrm{III})$ complexes. In consequence, for the coming paper, we intend to check whether $\mathrm{Ru}(\mathrm{II})$ complex can be active under the effect of light if it is in a triplet charge state. This will certainly be a tremendous breakthrough for therapeutic research.

\section{Conflicts of Interest}

The authors declare no conflicts of interest regarding the publication of this paper.

\section{References}

[1] Clarke, M.J., Zhu, F. and Frasca, D.R. (1999) Non-Platinum Chemotherapeutic Metallopharmaceuticals. Chemical Reviews, 99, 2511-2534.

https://doi.org/10.1021/cr9804238

[2] Chen, H.M. Parkinson, J.A., Parson, S., Coxall, R.A., Grould, R.O. and Sadler, P.J. (2002) Organometallic Ruthenium(II) Diamine Anticancer Complexes: AreneNucleobase Stacking and Stereospecific Hydrogen-Bonding in Guanine Adducts. Journal of the American Chemical Society, 124, 3064-3082. https://doi.org/10.1021/ja017482e

[3] Urruticoechea, A., Alemany, R., Balart, J., Villanueva, A., Viñals, F. and Capellá, G. (2010) Recent Advances in Cancer Therapy: An Overview. Current Pharmaceutical Design, 16, 3-10. https://doi.org/10.2174/138161210789941847

[4] Pieter, P. and Lippard, S.J. (1997) Cisplatin and Related Drugs. Encyclopedia of Cancer, 1, 525-543.

[5] Zhang, C.X. and Lippard, S.J. (2003) New Metal Complexes as Potential Therapeu- 
tics, Current Opinion in Chemical Biology, 7, 481-489.

https://doi.org/10.1016/S1367-5931(03)00081-4

[6] Wong, E. and Giandomenico, C.M. (1999) Current Status of Platinum-Based Antitumor Drugs. Chemical Reviews, 99, 2451-2466. https://doi.org/10.1021/cr980420v

[7] Lebwohl, D. and Canetta, R. (1998) Clinical Development of Platinum Complexes in Cancer Therapy: An Historical Perspective and an Update. European Journal of Cancer, 34, 1522-1534. https://doi.org/10.1016/S0959-8049(98)00224-X

[8] Wang, D. and Lippard, S.J. (2005) Cellular Processing of Platinum Anticancer Drugs. Nature Review Drug Discovery, 4, 307-320. https://doi.org/10.1038/nrd1691

[9] Galanski, M., Jakupec, M.A. and Keppler, B.K. (2005) Update of the Preclinical Situation of Anticancer Platinum Complexes: Novel Design Strategies and Innovative Analytical Approaches. Current Medicinal Chemistry, 12, 2075-2094. https://doi.org/10.2174/0929867054637626

[10] Garazd, Y., Garazd, M. and Lesyk, R. (2017) Synthesis and Evaluation of Anticancer Activity of 6-Pyrazolinylcoumarin Derivatives. Saudi Pharmaceutical Journal, 25, 214-223. https://doi.org/10.1016/j.jsps.2016.05.005

[11] Morsy, S.A., Farahat, A.A., Nasr, M.N.A. and Tantawy, A.S. (2017) Synthesis, Molecular Modeling and Anticancer Activity of New Coumarin Containing Compounds. Saudi Pharmaceutical Journal, 25, 873-883. https://doi.org/10.1016/j.jsps.2017.02.003

[12] Jamieson, E. and Lippard, S. (1999) Structure, Recognition, and Processing of Cisplatin-DNA Adducts. Chemical Reviews, 99, 2467-2498.

https://doi.org/10.1021/cr980421n

[13] Antonarakis, E.S. and Emadi, A. (2010) Ruthenium-Based Chemotherapeutics: Are They Ready for Prime Time? Cancer Chemotherapy and Pharmacology, 66, 1-9. https://doi.org/10.1021/cr9804238

[14] Clarke, M.J., Zhu, F. and Frasca, D.R. (1999) Non-Platinum Chemotherapeutic Metallopharmaceuticals. Chemical Reviews, 99, 2511-2534.

[15] Chen, J.C., Li, J.L., Qian, L. and Zheng, K.C. (2005) Electronic Structures and SARs of the Isomeric Complexes $\alpha$-, $\beta$-, $\gamma$ - $\left[\mathrm{Ru}(\text { mazpy })_{2} \mathrm{Cl}_{2}\right]$ with Different Antitumor Activities. Journal of Molecular Structure: THEOCHEM, 728, 93-101. https://doi.org/10.1016/j.theochem.2005.05.005

[16] Notaro, A. and Gasser, G. (2017) Monomeric and Dimeric Coordinatively Saturated and Substitutionally Inert Ru(II) Polypyridyl Complexes as Anticancer Drug Candidates. Chemical Society Reviews, 46, 7317-7337. https://doi.org/10.1039/C7CS00356K

[17] Zhu, B.-Z., Chao, X.-J., Huang, C.-H. and Li, Y. (2016) Delivering the Cell-Impermeable DNA “Light-Switching” Ru(ii) Complexes Preferentially into Live-Cell Nucleus via an Unprecedented Ion-Pairing Method. Chemical Science, 7, 4016-4023. https://doi.org/10.1039/C5SC03796D

[18] Jenkins, Y., Friedman, A.E., Turro, N.J. and Barton, J.K. (1992) Characterization of Dipyridophenazine Complexes of Ruthenium(II): The Light Switch Effect as a Function of Nucleic Acid Sequence and Conformation. Biochemistry, 31, 10809-10816. https://doi.org/10.1021/bi00159a023

[19] Liu, J.-G., Ye, B.-H., Li, H., Zhen, Q.-X., Ji, L.-N. and Fu, Y.-H. (1999) Polypyridyl Ruthenium(II) Complexes Containing Intramolecular Hydrogen-Bond Ligand: Syntheses, Characterization, and DNA-Binding Properties. Journal of Inorganic Biochemistry, 76, 265-271. https://doi.org/10.1016/S0162-0134(99)00154-3

[20] Bamba, K., Leger, J.-M., Garnier, E., Bachmann, C., Servat, K. and Kokoh, K.B. 
(2005) Selective Electro-Oxidation of D-Glucose by $\mathrm{RuCl}_{2}(\text { azpy })_{2}$ Complexes as Electrochemical Mediators. Electrochimica Acta, 50, 3341-3346. https://doi.org/10.1016/j.electacta.2004.12.007

[21] De Sousa, K., Chagas, M., dos Santos, J., Galvão, A., de Moraes, F., Ribeiro, A., Fortaleza, D., da Encarnação Amorim, K. and dos Santos, W. (2018) Theoretical and Comparative Study of the Complex $\left[\mathrm{RuCl}_{3}\left(\mathrm{H}_{2} \mathrm{O}\right)_{2}(\mathrm{Gly})\right]$ by Density Functional Theory. Open Journal of Inorganic Chemistry, 8, 43-53. https://doi.org/10.4236/ojic.2018.81004

[22] Vlan Vliet, P.M., Toekimin, S.M.S., Haasnoot, J.G., Reedijk, J., Novakova, O. and Brabec, V. (1995) mer-[Ru(terpy) $\left.\mathrm{Cl}_{3}\right]$ (terpy = 2,2':6',2"-terpyridine) Shows Biological Activity, Forms Interstrand Cross-Links in DNA and Binds Two Guanine Derivatives in a Trans Configuration. Inorganica Chimica Acta, 231, 57-64. https://doi.org/10.1016/0020-1693(94)04320-U

[23] Sava, G., Bergamo, A., Zorzet, S., Gava, B., Casarsa, C., Cocchietto, M., Furlani, A., Scarcia, V., Serli, B., Iengo, E., Alessio, E. and Mestroni, G. (2002) Influence of Chemical Stability on the Activity of the Antimetastasis Ruthenium Compound NAMI-A. European Journal of Cancer, 38, 427-435. https://doi.org/10.1016/S0959-8049(01)00389-6

[24] Chen, T., Liu, Y., Zheng, W.J., Liu, J. and Wong, Y.S. (2010) Ruthenium Polypyridyl Complexes that Induce Mitochondria-Mediated Apoptosis in Cancer Cells. Inorganic Chemistry, 49, 6366-6368. https://doi.org/10.1021/ic100277w

[25] Tan, C., Lai, S., Wu, S., Hu, S., Zhou, L., Chen, Y., Wang, M., Zhu, Y., Lian, W., Peng, W., Ji, L. and Xu, A. (2010) Nuclear Permeable Ruthenium(II) $\beta$-Carboline Complexes Induce Autophagy To Antagonize Mitochondrial-Mediated Apoptosis. Journal of Medicinal Chemistry, 53, 7613-7624. https://doi.org/10.1021/jm1009296

[26] Chagas, M.A.S., Galvão, A.D., de Moraes, F.T., Ribeiro, A.T.B.N., de Siqueira, A.B., de Assis Salama, I.C.C., Arrais-Silva, W.W., de Sousa, K.M.D., de Sousa Pereira, C.C. and dos Santos, W.B. (2017) Synthesis, Characterization and Analysis of Leishmanicide Ability of the Compound $\left[\mathrm{Ru}(\mathrm{Cl})_{3}\left(\mathrm{H}_{2} \mathrm{O}\right)_{2}(\mathrm{gly})\right]$. Open Journal of Inorganic Chemistry, 7, 89-101. https://doi.org/10.4236/ojic.2017.74006

[27] N'guessan, K.N., Guy-Richard Koné, M., Bamba, K., Wawohinlin Patrice, O. and Ziao, N. (2017) Quantitative Structure Anti-Cancer Activity Relationship (QSAR) of a Series of Ruthenium Complex Azopyridine by the Density Functional Theory (DFT) Method. Computational Molecular Bioscience, 7, 19-31. https://doi.org/10.4236/cmb.2017.72002

[28] Velders, A.H., Van der Schilden, K., Hoste, A.C.G., Reedijk, J., Kooijman, H. and Speck, A.L. (2004) Dichlorobis(2-phenylazopyridine)ruthenium(II) Complexes: Characterization, Spectroscopic and Structural Properties of Four Isomers. Dalton transactions, 3, 448-455. https://doi.org/10.1039/B313182C

[29] Hotze, A.C.G., Velders, A.H., Ugozzoli, F., Biagini-Cingi, M., Manotti-Lanfredi, A.M., Haasnoot, J.G. and Reedijk, J. (2000) Synthesis, Characterization, and Crystal Structure of $\alpha$-[Ru(azpy) $\left.{ }_{2}\left(\mathrm{NO}_{3}\right)_{2}\right]$ (azpy $=2$-(Phenylazo)pyridine) and the Products of Its Reactions with Guanine Derivatives. Inorganic Chemistry, 39, 3838-3844. https://doi.org/10.1021/ic000066v

[30] Bamba, K., Ouattara, W.P., N’Guessan, K.N. and Ziao, N. (2016) SARs Investigation of $\alpha$-, $\beta-, \gamma^{-}, \delta$-, $\varepsilon-\mathrm{RuCl}_{2}(\mathrm{Azpy})_{2}$ Complexes as Antitumor Drugs. Computational Chemistry, 4, 1-10. https://doi.org/10.4236/cc.2016.41001

[31] Novakova, O., Kasparkova, J., Vrana, O., Van Vliet, P.M., Reedijk, J. and Brabec, V. (1995) Correlation between Cytotoxicity and DNA Binding of Polypyridyl Ruthenium Complexes. Biochemistry, 34, 12369-12378.

https://doi.org/10.1021/bi00038a034 
[32] Sava, G., Capozzi, I., Clerici, K., Gagliardi, G., Alessio, E. and Mestroni, G. (1998) Pharmacological Control of Lung Metastases of Solid Tumours by a Novel Ruthenium Complex. Clinical \& Experimental Metastasis, 16, 371-379. https://doi.org/10.1023/A:1006521715400

[33] Lentz, F., Drescher, A., Lindauer, A., Henke, M., Hilger, R.A., Hartinger, C.G., Scheulen, M.E., Dittrich, C., Keppler, B.K. and Jaehde, U. (2009) Pharmacokinetics of a Novel Anticancer Ruthenium Complex (KP1019, FFC14A) in a Phase I Dose-Escalation Study. Anti-Cancer Drugs, 20, 97-103. https://doi.org/10.1097/CAD.0b013e328322fbc5

[34] Trondl, R., Heffeter, P., Kowol, C.R., Jakupec, M.A., Berger, W. and Keppler, B.K. (2014) NKP-1339, the First Ruthenium-Based Anticancer Drug on the Edge to Clinical Application. Chemical Science, 5, 2925-2932. https://doi.org/10.1039/C3SC53243G

[35] Hartinger, C.G., Zorbas-Seifried, S., Jakupec, M.A., Kynast, B., Zorbas, H. and Keppler, B.K. (2006) From Bench to Bedside-Preclinical and Early Clinical Development of the Anticancer Agent Indazolium Trans-[tetrachlorobis(1H-indazole) ruthenate(III)] (KP1019 or FFC14A). Journal of Inorganic Biochemistry, 100, 891-904. https://doi.org/10.1016/j.jinorgbio.2006.02.013

[36] Hotze, A.C.G., van der Geer, E.P.L., Kooijman, H., Spek, A.L., Haasnoot, J.G. and Reedijk, J. (2005) Characterization by NMR Spectroscopy, X-Ray Analysis an Cytotoxic Activity of Ruthenium (II) Compound $\mathrm{Ru}\left(\mathrm{L}_{3}\right)\left(\mathrm{PF}_{6}\right)_{2}$, (L) 2-Phenylazopyridine or o-Tolylazopyridine and $\mathrm{Ru}\left(\mathrm{L}^{\prime} 2 \mathrm{~L}\right.$ ") $\quad\left(\mathrm{PF}_{6}\right)_{2} \quad(\mathrm{~L}$ ', L"=2-Phenylazopyrine or 2,2'bipyridine). European Journal of Inorganic Chemistry, 2005, 2648-2657. https://doi.org/10.1002/ejic.200500110

[37] Das, C., Saha, A., Hung, C.-H., Lee, G.-H., Peng, S.-M. and Goswami, S. (2003) Ruthenium Complexes of 2-[(4-(Arylamino)phenyl)azo]pyridine Formed via Regioselective Phenyl Ring Amination of Coordinated 2-(Phenylazo)pyridine: Isolation of Products, X-ray Structure, and Redox and Optical Properties. Inorganic Chemistry, 42, 198-204. https://doi.org/10.1021/ic0203724

[38] Liu, J., Zou, X.-H., Zhang, Q.-L., Mei, W.-J., Liu, J.-Z. and Ji, L.-N. (2000) Synthesis, Characterization and Antitumor Activity of a Series of Polypyridyl Complexes. Metal-Based Drugs, 7, Article ID: 427618. https://doi.org/10.1155/MBD.2000.343

[39] Dwyer, F.P., Gyarfas, E.C., Rogers, W.P. and Koch, J.H. (1952) Biological Activity of Complex Ions. Nature, 170, 190-191. https://doi.org/10.1038/170190a0

[40] Allardyce, C.S. and Dyson, P.J. (2001) Ruthenium in Medicine: Current Clinical Uses and Future Prospects. Platinum Metals Review, 45, 62-69.

[41] Frisch, M.J., Trucks, G.W., Schlegel, H.B., Scuseria, G.E., Robb, M.A., Cheeseman, J.R., Scalmani, G., Barone, V., Mennucci, B., Petersson, G.A., Nakatsuji, H., Caricato, M., Li, X., Hratchian, H.P., Izmaylov, A.F., Bloino, J., Zheng, G., Sonnenberg, J.L., Hada, M., Ehara, M., Toyota, K., Fukuda, R., Hasegawa, J., Ishida, M., Nakajima, T., Honda, Y., Kitao, O., Nakai, H., Vreven, T., Montgomery Jr., J.A., Peralta, J.E., Ogliaro, F., Bearpark, M.J., Heyd, J., Brothers, E.N., Kudin, K.N., Staroverov, V.N., Kobayashi, R., Normand, J., Raghavachari, K., Rendell, A.P., Burant, J.C., Iyengar, S.S., Tomasi, J., Cossi, M., Rega, N., Millam, N.J., Klene, M., Knox, J.E., Cross, J.B., Bakken, V., Adamo, C., Jaramillo, J., Gomperts, R., Stratmann, R.E., Yazyev, O., Austin, A.J., Cammi, R., Pomelli, C., Ochterski, J.W., Martin, R.L., Morokuma, K., Zakrzewski, V.G., Voth, G.A., Salvador, P., Dannenberg, J.J., Dapprich, S., Daniels, A.D., Farkas, Ö., Foresman, J.B., Ortiz, J.V., Cioslowski, J. and Fox, D.J. (2009) Gaussian 09. Gaussian, Inc. Print, Wallingford. 
[42] Shriver, D.F. and Atkins, P.W. (1999) Inorganic Chemistry. 3rd Edition, De Boeck University, Paris, p. 229.

[43] Nobel, N.K., Bamba, K., Patrice, O.W. and Ziao, N. (2017) NBO Population Analysis and Electronic Calculation of Four Azopyridine Complexes by DFT Method. Computational Chemistry, 5, 51-64. https://doi.org/10.4236/cc.2017.51005

[44] Kurita, N. and Kobayashi, K. (2000) Density Functional MO Calculation for Stacked DNA Base-Pairs with Backbones. Computers \& Chemistry, 24, 351-357. https://doi.org/10.1016/S0097-8485(99)00071-6

[45] Velders, A.H., Kooijman, H., Spek, A.L., Haasnoot, J.G., De Vos, D. and Reedijk, J. (2000) Strong Differences in the in Vitro Cytotoxicity of Three Isomeric Dichlorobis(2-phenylazopyridine)ruthenium(II) Complexes. Inorganic Chemistry, 39, 29662967. https://doi.org/10.1021/ic000167t

[46] Zhao, X., Zheng, Z., Feng, S., Shi, Z. and Chen, D. (2009) A TD-DFT Study on the Photo-Physicochemical Properties of Chrysophanol from Rheum. International Journal of Molecular Sciences, 10, 3186-3193. https://doi.org/10.3390/ijms10073186

[47] Liu, J., Zhao, Y.W., Zhao, J.Q., Xia, A.D., Jiang, L.J., Wu, S., Ma, L., Dong, Y.Q. and Gu, Y.H. (2002) Two-Photon Excitation Studies of Hypocrellins for Photodynamic Therapy. Journal of Photochemistry and Photobiology B: Biology, 68, 156-164. https://doi.org/10.1016/S1011-1344(02)00379-2

[48] Wu, W., Shao, X., Zhao, J. and Wu, M. (2017) Controllable Photodynamic Therapy Implemented by Regulating Singlet Oxygen Efficiency. Advanced Science, 4, 1700113. https://doi.org/10.1002/advs.201700113

[49] Ouattara, W., Bamba, K., Thomas, A., Diarrassouba, F., Ouattara, L., Ouattara, M., N'guessan, K., Kone, M., Kodjo, C. and Ziao, N. (2021) Theoretical Studies of Photodynamic Therapy Properties of Azopyridine $\delta$ - $\mathrm{OsCl}_{2}$ (Azpy) ${ }_{2}$ Complex as a Photosensitizer by a TDDFT Method. Computational Chemistry, 9, 64-84. https://doi.org/10.4236/cc.2021.91004

[50] Rodica-Mariana, I. (2007) Photodynamic Therapy (PDT): A Photochemical Concept with Medical Applications. Revue Roumaine de Chimie, 52, 1093-1102.

[51] de Oliveira, K.T., de Souza, J.M., Gobo, N.R.S., de Assis, F.F. and Brocksom, T.J. (2015) Basic Concepts and Applications of Porphyrins, Chlorins and Phthalocyanines as Photosensitizers in Photonic Therapies. Revista Virtual de Quimica, 7, 310-335. https://doi.org/10.5935/1984-6835.20150016

[52] Musa, K.A.K., Matxain, J.M. and Eriksson, L.A. (2007) Mechanism of Photoinduced Decomposition of Ketoprofen. Journal of Medicinal Chemistry, 50, 1735-1743. https://doi.org/10.1021/jm060697k

[53] Sousa, F.F.R., Quartarolo, A.D., Sicilia, E. and Russo, N. (2012) A Time-Dependent Density Functional Study of a Non-Aromatic [1.1.1.1.1]-Pentaphyrin and Its Lutetium Complex. The Journal of Physical Chemistry B, 116, 10816-10823. https://doi.org/10.1021/jp3068359

[54] Shen, L., Ji, H.F. and Zhang, H.Y. (2006) A TD-DFT Study on Photo-Physicochemical Properties of Hypocrellin A and Its Implications for Elucidating the Photosensitizing Mechanisms of the Pigment. Journal of Photochemistry and Photobiology A: Chemistry, 180, 65-68. https://doi.org/10.1016/j.jphotochem.2005.09.019 